\title{
A Platinum Monolayer Core-Shell Catalyst with a Ternary Alloy Nanoparticle Core and Enhanced Stability for the Oxygen Reduction Reaction
}

\author{
Haoxiong Nan, Xinlong Tian, Lijun Yang, Ting Shu, Huiyu Song, and Shijun Liao \\ The Key Laboratory of Fuel Cell Technology of Guangdong Province and The Key Laboratory of New Energy of \\ Guangdong Universities, School of Chemistry and Chemical Engineering, South China University of Technology, \\ Wushan Road, Guangzhou, Guangdong 510640, China
}

Correspondence should be addressed to Shijun Liao; chsjliao@scut.edu.cn

Received 7 May 2015; Accepted 24 June 2015

Academic Editor: Hongmei Luo

Copyright (C) 2015 Haoxiong Nan et al. This is an open access article distributed under the Creative Commons Attribution License, which permits unrestricted use, distribution, and reproduction in any medium, provided the original work is properly cited.

\begin{abstract}
We synthesize a platinum monolayer core-shell catalyst with a ternary alloy nanoparticle core of Pd, Ir, and Ni. A Pt monolayer is deposited on carbon-supported PdIrNi nanoparticles using an underpotential deposition method, in which a copper monolayer is applied to the ternary nanoparticles; this is followed by the galvanic displacement of $\mathrm{Cu}$ with $\mathrm{Pt}$ to generate a Pt monolayer on the surface of the core. The core-shell $\mathrm{Pd}_{1} \mathrm{Ir}_{1} \mathrm{Ni}_{2} @ \mathrm{Pt} / \mathrm{C}$ catalyst exhibits excellent oxygen reduction reaction activity, yielding a mass activity significantly higher than that of Pt monolayer catalysts containing PdIr or PdNi nanoparticles as cores and four times higher than that of a commercial Pt/C electrocatalyst. In $0.1 \mathrm{M} \mathrm{HClO}_{4}$, the half-wave potential reaches $0.91 \mathrm{~V}$, about $30 \mathrm{mV}$ higher than that of Pt/C. We verify the structure and composition of the carbon-supported PdIrNi nanoparticles using X-ray powder diffraction, $\mathrm{X}$ ray photoelectron spectroscopy, thermogravimetry, transmission electron microscopy, and energy dispersive X-ray spectrometry, and we perform a stability test that confirms the excellent stability of our core-shell catalyst. We suggest that the porous structure resulting from the dissolution of $\mathrm{Ni}$ in the alloy nanoparticles may be the main reason for the catalyst's enhanced performance.
\end{abstract}

\section{Introduction}

Although proton exchange membrane fuel cells (PEMFCs) are recognized as a promising form of technology to meet the global energy crisis and address various associated environmental problems, many technical and economic challenges prevent their large-scale commercialization, one of which is the high cost of platinum [1]. Despite the fact that numerous efforts have been paid to search for substitute materials for platinum, such as Pd [2], Ir [3], $\mathrm{Ag}$ [4], $\mathrm{Au}$ [5], Fe- and N-doped carbon catalyst [6], and carbon nanotube/ $\mathrm{Fe}_{3} \mathrm{C}$ nanoparticle [7], a platinum-based catalyst is still the best choice for oxygen reduction in an acidic environment. In recent years, the emergence of coreshell catalysts [8-12], especially those with a Pt monolayer [13-20], has brought PEMFC commercialization closer to becoming a reality, because the mass activity of Pt in a coreshell catalyst can be enhanced by several times. However, most current core-shell catalysts still use precious metals (such as Pd $[21,22]$ ) as the cores, and this makes it difficult to reduce the cost of catalysts effectively. To address this problem, some studies have introduced nonprecious metals into the alloy nanoparticles, yielding cores such as $\mathrm{PdCo}, \mathrm{PdNi}$, and PdFe [23-25]. However, catalyst stability has remained a problem. Kuttiyiel et al. reported that an electrocatalyst's stability could be significantly enhanced by adding a negligible amount of Au to the PdNi nanoparticle core [25]. Knupp et al. found that the stability of a Pd@Pt/C catalyst could be improved by adding iridium to the Pd core [26].

In this study, we prepared a Pt monolayer core-shell catalyst with a ternary PdIrNi alloy nanoparticle as the core using an underpotential deposition (UPD) method. As expected, this catalyst exhibited superior oxygen reduction reaction (ORR) activity to a commercial $\mathrm{Pt} / \mathrm{C}$ catalyst as well as enhanced stability. 


\section{Experimental}

2.1. Preparation of Carbon-Supported PdIrNi Nanoparticles. The carbon-supported ternary alloy nanoparticles were prepared as follows. Palladium chloride, iridium chloride, and nickel chloride in an atomic ratio of $1: 1: 2$ were added to deionized water to obtain a solution. Next, sodium citrate was added as a complexing agent using a metal/citrate molar ratio of $1: 5$, after which carbon black $\mathrm{XC}-72 \mathrm{R}$ was added to the solution under strong stirring. After the mixture was purged with high-purity $\mathrm{N}_{2}$ for 15 minutes, excess $\mathrm{NaBH}_{4}$ solution (10 wt \%) was slowly added, using ultrasonication and under the protection of nitrogen. After reaction with ultrasonication for one hour, the mixture was filtered and washed with deionized water three to five times and then dried overnight in a vacuum oven at $50^{\circ} \mathrm{C}$. For comparison, binary nanoparticles of $\mathrm{PdNi}, \mathrm{IrNi}$, and PdIr were prepared using the same procedures. The metal content in each of the samples was $20 \mathrm{wt} \%$.

\subsection{Synthesis of Core-Shell Catalyst on Glassy Carbon} Electrode by UPD. The $\mathrm{Pt}$ monolayer core-shell catalyst PdIrNi@Pt/C was prepared on a glassy carbon electrode using a UPD method. First, $5.0 \mathrm{mg}$ carbon-supported ternary PdIrNi alloy nanoparticles were dispersed in $1 \mathrm{~mL}$ Nafion ethanol solution $(0.1 \mathrm{wt} \%)$ via ultrasonication for 30 minutes to make a uniform suspension. Then, $5 \mu \mathrm{L}$ of the suspension was pipetted onto a glassy carbon disk electrode ( $5 \mathrm{~mm}$ diameter) and dried in air. Next, a Cu monolayer was deposited on the surface of the PdIrNi nanoparticles in a $0.05 \mathrm{M} \mathrm{H}_{2} \mathrm{SO}_{4}+$ $0.05 \mathrm{M} \mathrm{CuSO}_{4}$ solution by holding the deposition potential at about $0.37 \mathrm{~V}$ for one minute, under the protection of highpurity nitrogen. Finally, the electrode was transferred into a solution of $1 \mathrm{mM} \mathrm{K}_{2} \mathrm{PtCl}_{4}+0.05 \mathrm{M} \mathrm{H}_{2} \mathrm{SO}_{4}$ for 10 minutes in a nitrogen atmosphere, in which the $\mathrm{Cu}$ monolayer was galvanically replaced by $\mathrm{Pt}$ to form a $\mathrm{Pt}$ monolayer. The theoretical Pt content in the catalyst was calculated from the UPD charge of $\mathrm{Cu}$, and the real content was determined by inductively coupled plasma-atomic emission spectrometry (ICP-AES).

This prepared electrode bearing the core-shell structured catalyst was used for the subsequent electrochemical performance measurements without further treatment.

\subsection{Measurement of the Catalysts' Electrochemical Perfor-} mance. The electrochemical performance of the catalysts was measured by cyclic voltammetry $(\mathrm{CV})$ on an electrochemical workstation (Ivium, Netherlands) using a threeelectrode electrochemical cell. An $\mathrm{Ag} / \mathrm{AgCl} / \mathrm{KCl}$ (3 M) leakfree reference electrode and a Pt wire were used as the reference and counter electrodes, respectively. ORR and hydrogen underpotential deposition (HUPD) measurements were performed in $0.1 \mathrm{M} \mathrm{HClO}_{4}$ solution saturated with oxygen and nitrogen at room temperature.

2.4. Catalyst Characterization. X-ray powder diffraction (XRD) patterns were obtained with a TD-3500 powder diffractometer (Tongda, China) using filtered $\mathrm{Cu}-\mathrm{K} \alpha$ radiation operating at $40 \mathrm{kV}$ and $30 \mathrm{~mA}$. Scanning transmission electron microscope (STEM) images were recorded on a JEOL JEM $2100 \mathrm{~F}$ operated at $200 \mathrm{kV}$. Thermogravimetric (TG) analyses were performed on a Q600 SDT analyzer (TA Inc., USA $)$ in a pure nitrogen flow $\left(100 \mathrm{~mL} \mathrm{~min}^{-1}\right)$ at a heating rate of $10^{\circ} \mathrm{C} \mathrm{min}^{-1}$ from room temperature to $950^{\circ} \mathrm{C}$. $\mathrm{X}$ ray photoelectron spectroscopy (XPS) was performed on an Axis Ultra DLD X-ray photoelectron spectrometer (Kratos, England) employing a monochromated Al-K $\alpha$ X-ray source $(h \nu=1486.6 \mathrm{eV})$. ICP-AES (Leema PROFILE, America) was used to analyze the contents of trace metal elements.

\section{Results and Discussion}

3.1. Characterization. The structures of the as-prepared catalysts were characterized by XRD (Figure 1). The first peak, located at about $23.2^{\circ}$, refers to the Vulcan XC72 carbon support. The diffraction peaks at the $2 \theta$ values of $42.5^{\circ}$ for the PdIrNi/C catalysts readily correspond to the (111) crystal planes of the face-centered cubic crystalline structure. As shown in Figure 1(a), the (111) diffraction peak of $\mathrm{Pd}_{1} \mathrm{Ir}_{1} \mathrm{Ni}_{2} @ \mathrm{Pt} / \mathrm{C}$ has shrunk sharply and shifted negatively slightly (about $0.8^{\circ}$ ) compared to that of $\mathrm{Pd}_{1} \mathrm{Ir}_{1} \mathrm{Ni}_{2} / \mathrm{C}$; we suggest this is due to the dissolution of $\mathrm{Ni}$ from the alloy nanoparticles during the UPD process, and the results of the ICP-AES analysis confirm this explanation.

It should be pointed out that no diffraction peaks corresponding to $\mathrm{Pt}$ could be observed in the XRD pattern of $\mathrm{Pd}_{1} \mathrm{Ir}_{1} \mathrm{Ni}_{2} @ \mathrm{Pt} / \mathrm{C}$, perhaps because the Pt monolayer could not generate diffractions.

It is interesting that no diffraction peaks of $\mathrm{Ni}$ and $\mathrm{Ir}$ could be observed for the $\mathrm{Pd}_{1} \mathrm{Ir}_{1} \mathrm{Ni}_{2} / \mathrm{C}$ sample, even though the $\mathrm{Ni}$ and Ir contents were up to 50 at \% and 25 at \%, respectively. There may be two reasons: (1) the Ni atoms entered the Pd lattice to form a complete alloy; (2) Ni formed an X-ray amorphous phase that will not be observed in the diffractogram. Figure 1(b) shows the XRD patterns of the $\mathrm{PdIrNi} / \mathrm{C}$ catalysts with a $\mathrm{Pd} / \mathrm{Ir}$ ratio of 1 and various $\mathrm{Pd} / \mathrm{Ni}$ ratios. The lattice parameters of $\mathrm{Pd}_{1} \mathrm{Ir}_{1} / \mathrm{C}, \mathrm{Pd}_{2} \mathrm{Ir}_{2} \mathrm{Ni}_{1} / \mathrm{C}$, $\mathrm{Pd}_{1} \mathrm{Ir}_{1} \mathrm{Ni}_{2} / \mathrm{C}$, and $\mathrm{Pd}_{1} \mathrm{Ir}_{1} \mathrm{Ni}_{8} / \mathrm{C}$ were $3.873,3.783,3.688$, and $3.681 \AA$ calculated from the (111) diffraction plane by Jade software. The atomic radii of $\mathrm{Pd}, \mathrm{Ir}$, and $\mathrm{Ni}$ atoms are $1.37,1.36$, and $1.25 \AA$, respectively. When more $\mathrm{Ni}$ atoms entered into the Pd lattice, it can result in the decrease of the lattice parameter and the $\mathrm{Pd}-\mathrm{Pd}$ interatomic distance because the radius of the $\mathrm{Ni}$ atom was smaller than that of the Pd atom [27]. Clearly, the (111) diffraction peak for the catalysts shifted positively as the Ni content increased, and the lattice parameters decreased obviously with the increase of the content of nickel.

Figure 2 presents TEM images of the $\operatorname{Pd}_{1} \operatorname{Ir}_{1} / \mathrm{C}$, $\mathrm{Pd}_{1} \mathrm{Ir}_{1} @ \mathrm{Pt} / \mathrm{C}, \mathrm{Pd}_{1} \mathrm{Ir}_{1} \mathrm{Ni}_{2} / \mathrm{C}$, and $\mathrm{Pd}_{1} \mathrm{Ir}_{1} \mathrm{Ni}_{2} @ \mathrm{Pt} / \mathrm{C}$ catalysts. It can be observed that all of the nanoparticles were well dispersed on the carbon support without apparent aggregation either before or after the $\mathrm{Pt}$ deposition. The $\mathrm{Pd}_{1} \mathrm{Ir}_{1} / \mathrm{C}$ and $\mathrm{Pd}_{1} \mathrm{Ir}_{1} \mathrm{Ni}_{2} / \mathrm{C}$ nanoparticles exhibited a rather narrow size distribution, in the range of 1-3.5 and 1.25$2.5 \mathrm{~nm}$, with average diameters of about 2.2 and $1.7 \mathrm{~nm}$, respectively, which are in agreement with the particle results predicted by XRD. On the basis of the high-resolution 


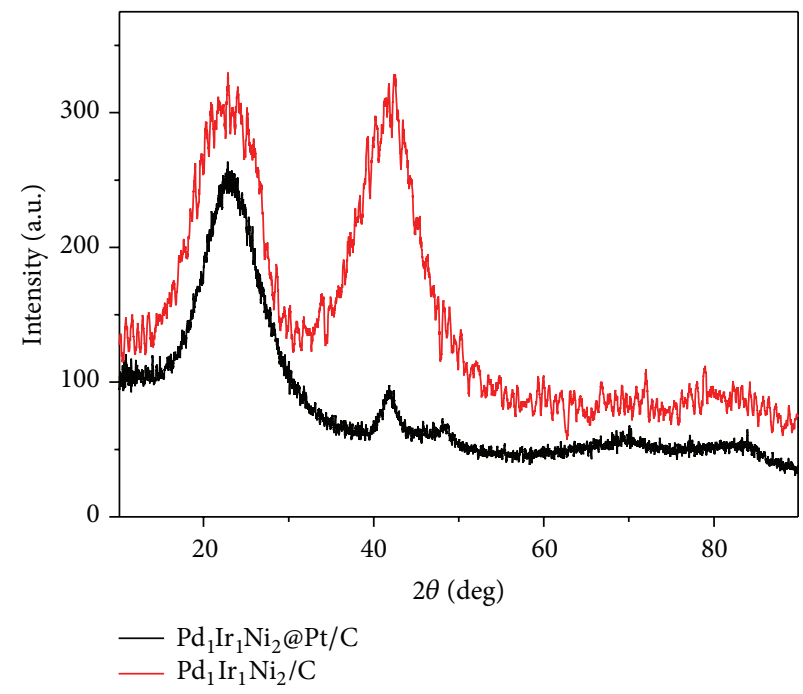

(a)

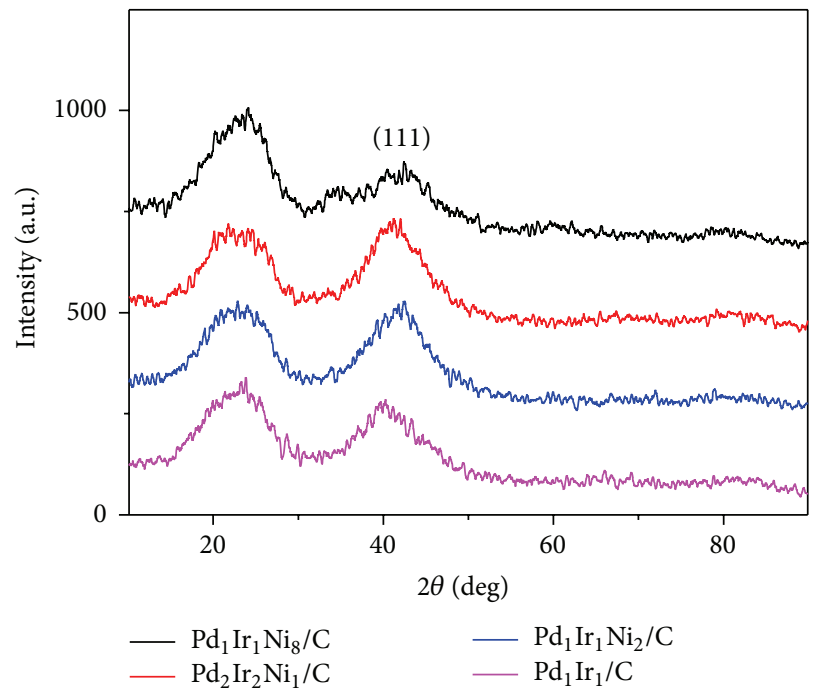

(b)

Figure 1: (a) XRD patterns of the $\mathrm{Pd}_{1} \mathrm{Ir}_{1} \mathrm{Ni}_{2} / \mathrm{C}$ and $\mathrm{Pd}_{1} \mathrm{Ir}_{1} \mathrm{Ni}_{2} @ \mathrm{Pt} / \mathrm{C}$ catalysts. (b) XRD patterns of PdIrNi/C catalysts with different atomic ratios.

TEM (HRTEM) shown in Figures 2(b) and 2(f), there was a decrease of the lattice distance for $\mathrm{Pd}_{1} \mathrm{Ir}_{1} \mathrm{Ni}_{2} / \mathrm{C}(0.22 \mathrm{~nm})$ compared to that of $\mathrm{Pd}_{1} \mathrm{Ir}_{1} / \mathrm{C}(0.225 \mathrm{~nm})$, which can be explained by the addition of Ni. XRD measurements also demonstrated that lattice contraction occurred, as the (111) diffraction peak of $\mathrm{Pd}_{1} \mathrm{Ir}_{1} \mathrm{Ni}_{2} / \mathrm{C}$ showed a slight positive shift compared to that of $\operatorname{Pd}_{1} \operatorname{Ir}_{1} / C$. The smaller size and better dispersion observed for $\mathrm{Pd}_{1} \mathrm{Ir}_{1} \mathrm{Ni}_{2} / \mathrm{C}$ in comparison to $\mathrm{Pd}_{1} \mathrm{Ir}_{1} / \mathrm{C}$ can be attributed to the addition of $\mathrm{Ni}$ to the alloy.

After the deposition of $\mathrm{Pt}$, the $\mathrm{Pd}_{1} \mathrm{Ir}_{1} @ \mathrm{Pt} / \mathrm{C}$ and $\mathrm{Pd}_{1} \mathrm{Ir}_{1} \mathrm{Ni}_{2} @ \mathrm{Pt} / \mathrm{C}$ catalysts showed average diameters of $\sim 2.85$ and $\sim 2.30 \mathrm{~nm}$, respectively (see the size distributions provided in Figures 2(c) and 2(g)). The diameters of both nanoparticles increased by ca. $0.6 \mathrm{~nm}$, indicating that the thickness of the Pt shell layer was ca. $0.3 \mathrm{~nm}$, corresponding to a monolayer of $\mathrm{Pt}$ atoms. These results confirm the core-shell structure of $\mathrm{Pd}_{1} \mathrm{Ir}_{1} @ \mathrm{Pt} / \mathrm{C}$ and $\mathrm{Pd}_{1} \mathrm{Ir}_{1} \mathrm{Ni}_{2} @ \mathrm{Pt} / \mathrm{C}$. To obtain a better distribution of $\mathrm{Pd}, \mathrm{Ir}, \mathrm{Ni}$, and $\mathrm{Pt}$ in $\mathrm{Pd}_{1} \mathrm{Ir}_{1} \mathrm{Ni}_{2} @ \mathrm{Pt} / \mathrm{C}$, we employed high-angle annular dark field (HAADF) imaging and conducted a line-profile analysis using STEM/energy dispersive spectroscopy (EDS). As shown in Figures 2(i) and 2(j), the profile analysis revealed a lower intensity of $\mathrm{Pt}$ at the center than at the PdIrNi edges, suggesting the formation of a core (PdIrNi)/shell (Pt) structure. The lattice distances were found to be $0.217 \mathrm{~nm}$ for $\mathrm{Pd}_{1} \mathrm{Ir}_{1} @ \mathrm{Pt} / \mathrm{C}$ and $0.215 \mathrm{~nm}$ for $\mathrm{Pd}_{1} \mathrm{Ir}_{1} \mathrm{Ni}_{2} @ \mathrm{Pt} / \mathrm{C}$ (Figures 2(d) and $2(\mathrm{~h})$ ), compared to 0.225 and $0.22 \mathrm{~nm}$ for $\mathrm{Pd}_{1} \mathrm{Ir}_{1} / \mathrm{C}$ and $\mathrm{Pd}_{1} \mathrm{Ir}_{1} \mathrm{Ni}_{2} / \mathrm{C}$, respectively. The decrease of interplanar spacing was caused by the force between the core and the Pt shell.

The elements on the surfaces of the $\mathrm{Pd}_{1} \mathrm{Ir}_{1} \mathrm{Ni}_{2} / \mathrm{C}$, $\mathrm{Pd}_{1} \mathrm{Ir}_{1} \mathrm{Ni}_{2} @ \mathrm{Pt} / \mathrm{C}$, and $\mathrm{Pt} / \mathrm{C}$ catalysts were characterized by XPS. Figures 3(a) and 3(b) show the XPS survey spectra, and Figures 3(c)-3(h) show the Pd 3d, Ir 4f, and Pt $4 \mathrm{f}$ XPS spectra of $\mathrm{Pd}_{1} \mathrm{Ir}_{1} \mathrm{Ni}_{2} / \mathrm{C}, \mathrm{Pd}_{1} \mathrm{Ir}_{1} \mathrm{Ni}_{2} @ \mathrm{Pt} / \mathrm{C}$, and $\mathrm{Pt} / \mathrm{C}$. The binding energy was calibrated by means of the $\mathrm{C} 1 \mathrm{~s}$
TABLE 1: Results of fitting the XPS spectra; values given in percentage of total intensity.

\begin{tabular}{lccccccc}
\hline \multirow{2}{*}{ Sample } & \multicolumn{7}{c}{ Concentration (\%) } \\
& $\mathrm{Pd} 3 \mathrm{~d}$ & $\mathrm{Ir} 4 \mathrm{f}$ & $\mathrm{Ni} 2 \mathrm{p}$ & $\mathrm{Pt} 4 \mathrm{f}$ & $\mathrm{C} 1 \mathrm{~s}$ & $\mathrm{O} 1 \mathrm{~s}$ & $\mathrm{~F} 1 \mathrm{~s}$ \\
\hline $\mathrm{Pd}_{1} \mathrm{Ir}_{1} \mathrm{Ni}_{2} / \mathrm{C}$ & 1.92 & 1.8 & 2 & - & 82.02 & 12.25 & - \\
$\mathrm{Pd}_{1} \mathrm{Ir}_{1} \mathrm{Ni}_{2} @ \mathrm{Pt} / \mathrm{C}$ & 0.48 & 0.46 & - & 0.37 & 54.58 & 9.04 & 34.42 \\
\hline
\end{tabular}

peak energy of $284.56 \mathrm{eV}$. The results, given as percentages of total intensity, are presented in Table 1 . It can be seen that $\mathrm{Pd}_{1} \mathrm{Ir}_{1} \mathrm{Ni}_{2} @ \mathrm{Pt} / \mathrm{C}$ showed a decrease in Pd $3 \mathrm{~d}$ and Ir uf concentrations compared to $\mathrm{Pd}_{1} \mathrm{Ir}_{1} \mathrm{Ni}_{2} / \mathrm{C}$, even though the $\mathrm{Pd} / \mathrm{Ir}$ ratio was almost unchanged. Ni was not detected in the $\mathrm{Pd}_{1} \mathrm{Ir}_{1} \mathrm{Ni}_{2} @ \mathrm{Pt} / \mathrm{C}$ nanoparticles for two main reasons: first, most of the Ni nanoparticles leached out from the $\mathrm{Pd}_{1} \mathrm{Ir}_{1} \mathrm{Ni}_{2} / \mathrm{C}$; second, the strong $\mathrm{F}$ Auger $(833.0 \mathrm{eV})$ covered the peak of the Ni nanoparticles. The best fits of the Pd (0) $3 \mathrm{~d}$ spectra (Figure 3(a)) were obtained using two doublets $\left(\mathrm{Pd} 3 \mathrm{~d}_{5 / 2}\right.$ and $\left.3 \mathrm{~d}_{3 / 2}\right)$ with a fixed doublet separation (DS = $5.2 \mathrm{eV}$ ). This method revealed that the binding energy of Pd (0) 3d (336.5 and 341.7 eV) in $\mathrm{Pd}_{1} \mathrm{Ir}_{1} \mathrm{Ni}_{2} @ \mathrm{Pt} / \mathrm{C}$ experienced a positive shift of $0.3 \mathrm{eV}$ compared with that of $\mathrm{Pd}_{1} \mathrm{Ir}_{1} \mathrm{Ni}_{2} / \mathrm{C}$ (336.19 and $341.35 \mathrm{eV}$ ), and the binding energy of Ir (0) $4 \mathrm{f}$ (61.58 and 62.79 eV) in $\mathrm{Pd}_{1} \mathrm{Ir}_{1} \mathrm{Ni}_{2} @ \mathrm{Pt} / \mathrm{C}$ underwent a positive shift of $0.2 \mathrm{eV}$ compared with that of $\mathrm{Pd}_{1} \mathrm{Ir}_{1} \mathrm{Ni}_{2} / \mathrm{C}$ (61.39 and $62.6 \mathrm{eV}$ ). What is more, a clear negative shift of ca. $0.3 \mathrm{eV}$ in the binding energy of Pt $4 \mathrm{f}$ for $\mathrm{Pd}_{1} \mathrm{Ir}_{1} \mathrm{Ni}_{2} @ \mathrm{Pt} / \mathrm{C}$ catalyst with respect to the $20 \% \mathrm{JM}-\mathrm{Pt} / \mathrm{C}$ catalyst can be observed. These observations further confirmed the electron interactions involving the alloy core and $\mathrm{Pt}$ atoms within the $\mathrm{Pd}_{1} \mathrm{Ir}_{1} \mathrm{Ni}_{2} @ \mathrm{Pt} / \mathrm{C}$ catalyst. The negative shift of the Pt 4f binding energy implied that the Pt nanoparticles can get electrons from the alloy core, leading to a weakened interaction between intermediate oxide species and Pt atoms that the ORR was improved [28]. 


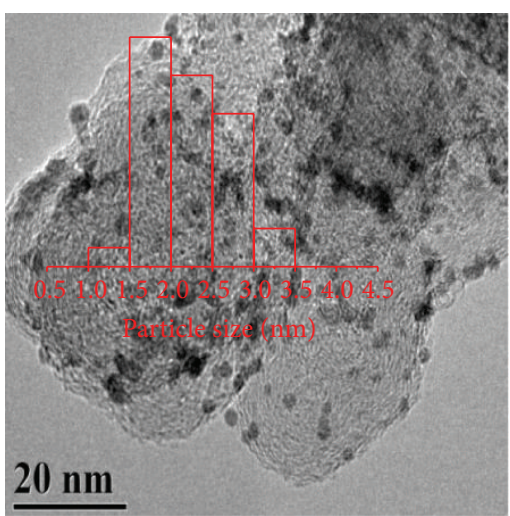

(a)

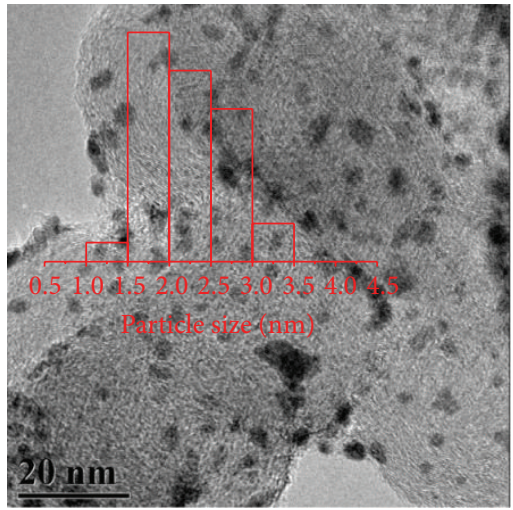

(c)

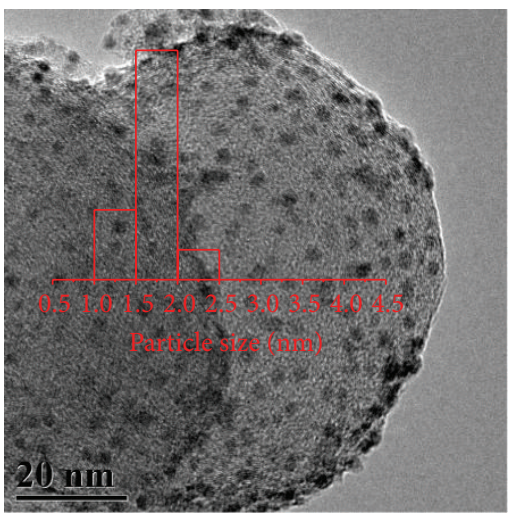

(e)

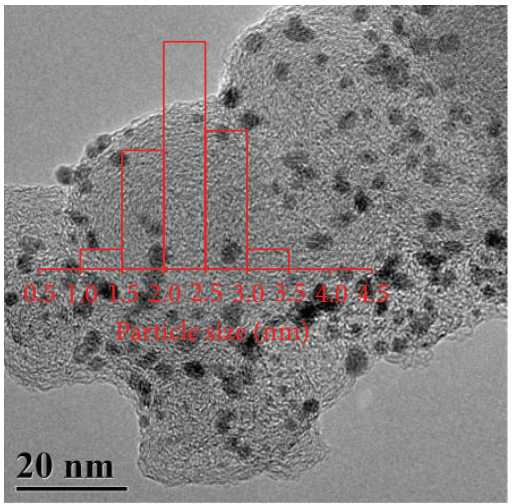

(g)

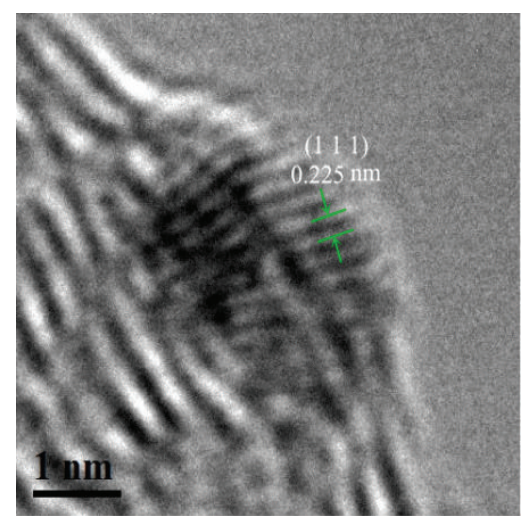

(b)

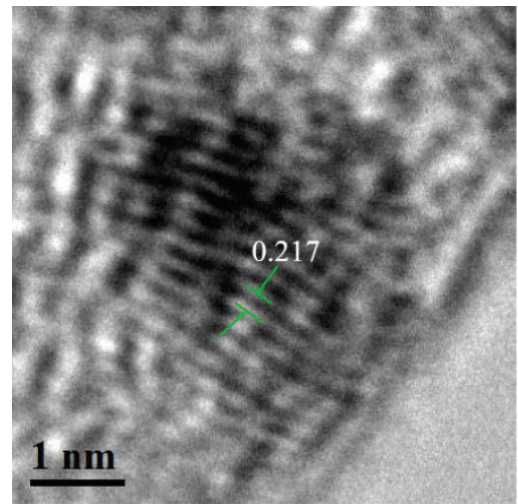

(d)

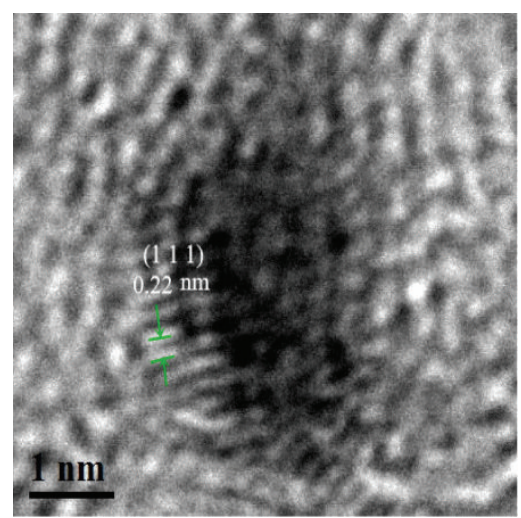

(f)

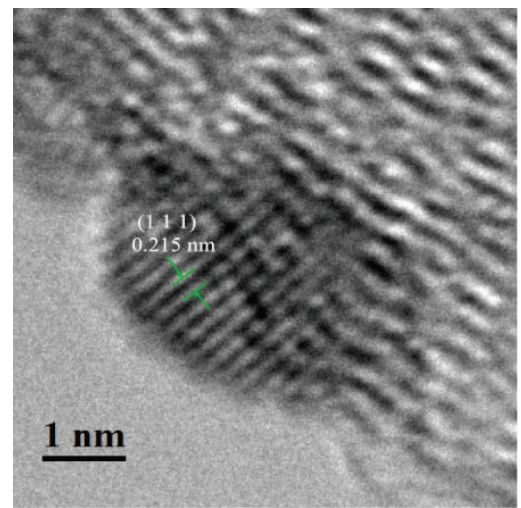

(h)

Figure 2: Continued. 


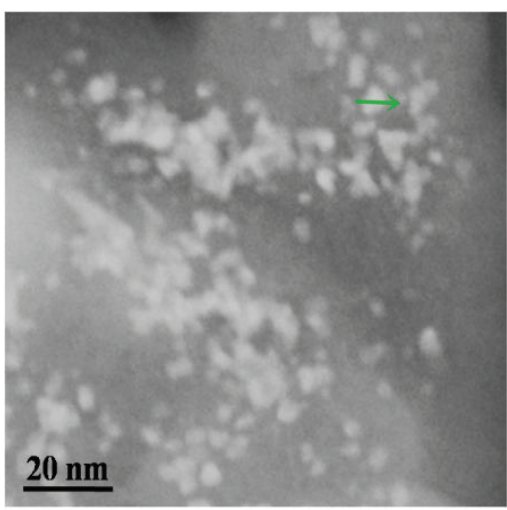

(i)

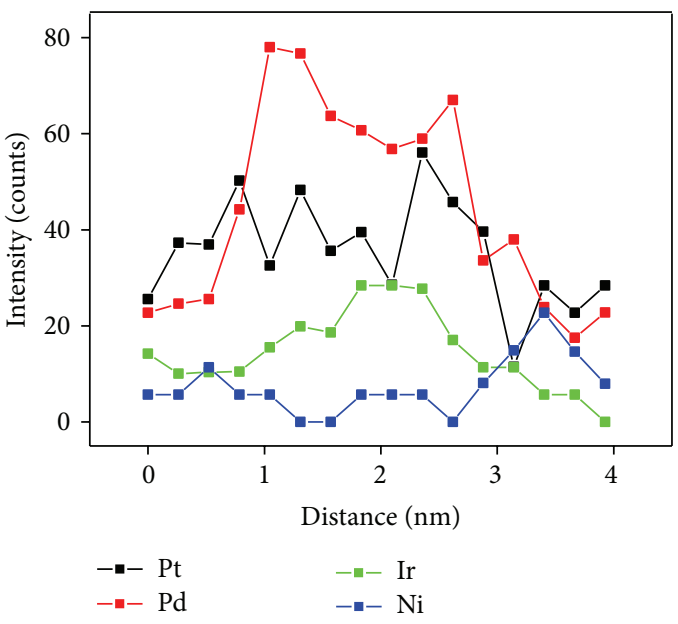

(j)

FIGURE 2: TEM images and the corresponding particle core size histograms (inset) of $\mathrm{Pd}_{1} \mathrm{Ir}_{1} / \mathrm{C}(\mathrm{a}), \mathrm{Pd}_{1} \mathrm{Ir}_{1} @ \mathrm{Pt} / \mathrm{C}(\mathrm{c}), \mathrm{Pd}_{1} \mathrm{Ir}_{1} \mathrm{Ni} \mathrm{i}_{2} / \mathrm{C}(\mathrm{e})$, and $\mathrm{Pd}_{1} \mathrm{Ir}_{1} \mathrm{Ni}_{2} @ \mathrm{Pt} / \mathrm{C}(\mathrm{g})$; the HRTEM images of $\mathrm{Pd}_{1} \mathrm{Ir}_{1} / \mathrm{C}(\mathrm{b}), \mathrm{Pd}_{1} \mathrm{Ir}_{1} @ \mathrm{Pt} / \mathrm{C}(\mathrm{d}), \mathrm{Pd}_{1} \mathrm{Ir}_{1} \mathrm{Ni}_{2} / \mathrm{C}$ (f), and $\mathrm{Pd}_{1} \mathrm{Ir}_{1} \mathrm{Ni}_{2} @ \mathrm{Pt} / \mathrm{C}$ (h); HAADF images of $\mathrm{Pd}_{1} \mathrm{Ir}_{1} \mathrm{Ni}_{2} @ \mathrm{Pt} / \mathrm{C}$ (i) and EDS analysis of $\mathrm{Pd}_{1} \mathrm{Ir}_{1} \mathrm{Ni}_{2} @ \mathrm{Pt} / \mathrm{C}(\mathrm{j})$.

3.2. Oxygen Reduction Reaction. Figure 4(a) shows the $\mathrm{CV}$ curves for $\operatorname{Pd}_{1} \mathrm{Ir}_{1} \mathrm{Ni}_{2} / \mathrm{C}, \mathrm{Pd}_{1} \mathrm{Ir}_{1} \mathrm{Ni}_{2} @ \mathrm{Pt} / \mathrm{C}, \mathrm{Pd}_{1} \mathrm{Ir}_{1} / \mathrm{C}$, and $\mathrm{Pd}_{1} \mathrm{Ir}_{1} @ \mathrm{Pt} / \mathrm{C}$ in deaerated $0.05 \mathrm{M} \mathrm{H}_{2} \mathrm{SO}_{4}$ at a scan rate of $50 \mathrm{mV} \mathrm{s}^{-1} \cdot \mathrm{Pd}_{1} \mathrm{Ir}_{1} \mathrm{Ni}_{2} / \mathrm{C}$ and $\mathrm{Pd}_{1} \mathrm{Ir}_{1} / \mathrm{C}$ clearly exhibited almost the same CV curves, apart from the slight positive shift in the position of the metal oxide reduction peak in $\mathrm{Pd}_{1} \mathrm{Ir}_{1} \mathrm{Ni}_{2} / \mathrm{C}$; both had almost the same hydrogen reduction and oxidation peaks. Conversely, it is interesting that, in the case of $\mathrm{Pd}_{1} \mathrm{Ir}_{1} @ \mathrm{Pt} / \mathrm{C}$ and $\mathrm{Pd}_{1} \mathrm{Ir}_{1} \mathrm{Ni}_{2} @ \mathrm{Pt} / \mathrm{C}, \mathrm{Pd}_{1} \mathrm{Ir}_{1} @ \mathrm{Pt} / \mathrm{C}$ exhibited obviously larger hydrogen reduction and oxidation peaks than $\mathrm{Pd}_{1} \mathrm{Ir}_{1} \mathrm{Ni}_{2} @ \mathrm{Pt} / \mathrm{C}$, and the reduction peaks of the surface metal oxide shifted from ca. $0.7 \mathrm{~V}$ to ca. $0.8 \mathrm{~V}$, clearly confirming that $\mathrm{Pt}$ was covering the core nanoparticles. It is important that the electrochemical surface area (ECSA) of $\mathrm{Pd}_{1} \mathrm{Ir}_{1} @ \mathrm{Pt} / \mathrm{C}\left(147.7 \mathrm{~m}^{2} \mathrm{~g}^{-1} \mathrm{Pt}\right)$ was higher than that of $\mathrm{Pd}_{1} \mathrm{Ir}_{1} \mathrm{Ni}_{2} @ \mathrm{Pt} / \mathrm{C}\left(114.5 \mathrm{~m}^{2} \mathrm{~g}^{-1} \mathrm{Pt}\right)$; however, the mass activity of $\mathrm{Pd}_{1} \mathrm{Ir}_{1} \mathrm{Ni}_{2} @ \mathrm{Pt} / \mathrm{C}$ was higher than that of PdIr@Pt/C, as we will discuss later. As shown in Figure 4(b), the deposition reduction peak and oxidation peak related to the $\mathrm{Cu}$ UPD can be observed on the $\mathrm{Pd}_{1} \mathrm{Ir}_{1} / \mathrm{C}$ and $\mathrm{Pd}_{1} \mathrm{Ir}_{1} \mathrm{Ni}_{2} / \mathrm{C}$ clearly. It is found that the peak area of $\mathrm{Pd}_{1} \mathrm{Ir}_{1} / \mathrm{C}$ was higher than that of $\mathrm{Pd}_{1} \mathrm{Ir}_{1} \mathrm{Ni} / \mathrm{C}$. The theoretical Pt contents in $\mathrm{Pd}_{1} \mathrm{Ir}_{1} @ \mathrm{Pt} / \mathrm{C}$ and $\mathrm{Pd}_{1} \mathrm{Ir}_{1} \mathrm{Ni}_{2} @ \mathrm{Pt} / \mathrm{C}$ catalysts by calculating from the UPD charge of Cu were $6.31 \mu \mathrm{g} \mathrm{cm}^{-2}$ and $5.21 \mu \mathrm{g} \mathrm{cm}^{-2}$, respectively.

Figure 5 shows the ORR polarization curves of $\mathrm{Pd}_{1} \mathrm{Ir}_{1} @ \mathrm{Pt} / \mathrm{C}, \mathrm{Pd}_{1} \mathrm{Ir}_{1} \mathrm{Ni}_{2} @ \mathrm{Pt} / \mathrm{C}, \quad \mathrm{IrNi} @ \mathrm{Pt} / \mathrm{C}, \mathrm{PdNi} @ \mathrm{Pt} / \mathrm{C}$, and $20 \% \mathrm{JM}-\mathrm{Pt} / \mathrm{C}$ at $1600 \mathrm{rpm}$ in oxygen-saturated $0.1 \mathrm{M} \mathrm{HClO}_{4}$ solution. The $\mathrm{Pd}_{1} \mathrm{Ir}_{1} \mathrm{Ni}_{2} @ \mathrm{Pt} / \mathrm{C}$ exhibited the best ORR activity, even superior to that of commercial $20 \% \mathrm{JM}-\mathrm{Pt} / \mathrm{C}$. The $\mathrm{Pt}$ loading of $\mathrm{Pd}_{1} \mathrm{Ir}_{1} \mathrm{Ni}_{2} @ \mathrm{Pt} / \mathrm{C}$ was $5.24 \mathrm{nmol}\left(5.22 \mu \mathrm{g} \mathrm{cm}^{-2}\right)$, and the PdIr loading was $24 \mathrm{nmol}$ $\left(18.29 \mu \mathrm{g} \mathrm{cm}^{-2}\right)$. The electrocatalyst's considerable activity was indicated by the high onset potential of $\mathrm{O}_{2}$ reduction $(0.9-1.05 \mathrm{~V})$ as well as by the high half-wave potential
$(885 \mathrm{mV}$ at a rotation rate of $1600 \mathrm{rpm})$. The mass activity of $\mathrm{Pd}_{1} \mathrm{Ir}_{1} \mathrm{Ni}_{2} @ \mathrm{Pt} / \mathrm{C}$ was 1.5 times that of $\mathrm{Pd}_{1} \mathrm{Ir}_{1} @ \mathrm{Pt} / \mathrm{C}$ and over four times that of commercial 20\% JM-Pt/C. Based on these results, we can conclude that (1) the high mass activity of $\mathrm{Pd}_{1} \mathrm{Ir}_{1} \mathrm{Ni}_{2} @ \mathrm{Pt} / \mathrm{C}$ may be strong evidence for the formation of a core-shell structured catalyst and (2) the addition of Ni may have played an important role in performance enhancement.

To further understand this excellent mass activity enhancement and the role of $\mathrm{Ni}$, we measured the real composition of all the catalysts, as shown in Table 2. For $\mathrm{Pd}_{1} \mathrm{Ir}_{1} \mathrm{Ni}_{2} @ \mathrm{Pt} / \mathrm{C}$ and $\mathrm{Pd}_{1} \mathrm{Ir}_{1} @ \mathrm{Pt} / \mathrm{C}$, the actual Pt contents were close to their theoretical contents: the deviations were 3.5\% for $\mathrm{Pd}_{1} \mathrm{Ir}_{1} \mathrm{Ni}_{2} @ \mathrm{Pt} / \mathrm{C}$ and $~ 13.7 \%$ for $\mathrm{Pd}_{1} \mathrm{Ir}_{1} @ \mathrm{Pt} / \mathrm{C}$. For all of the samples containing $\mathrm{Ni}$, we found that the $\mathrm{Ni}$ was almost totally removed during the scanning and UPD steps; for $\mathrm{Pd}_{1} \mathrm{Ir}_{1} \mathrm{Ni}_{2} @ \mathrm{Pt} / \mathrm{C}$, the $\mathrm{Ni}$ residue was only $0.05 \mu \mathrm{g} \mu \mathrm{g}^{-1}$ catalyst, which was just $0.05 \%$ of the $\mathrm{Ni}$ in the $\mathrm{Pd}_{1} \mathrm{Ir}_{1} \mathrm{Ni}_{2} / \mathrm{C}$ sample, indicating $99.5 \%$ of the $\mathrm{Ni}$ had been removed during the UPD process [29]. Clearly, $\mathrm{Pd}_{1} \mathrm{Ir}_{1} \mathrm{Ni}_{2} @ \mathrm{Pt} / \mathrm{C}$ contained less deposited $\mathrm{Pt}$ than $\mathrm{Pd}_{1} \mathrm{Ir}_{1} @ \mathrm{Pt} / \mathrm{C}$, and the UPD step removed the $\mathrm{Ni}$, so why did $\mathrm{Pd}_{1} \mathrm{Ir}_{1} \mathrm{Ni}_{2} @ \mathrm{Pt} / \mathrm{C}$ exhibit higher mass activity than $\mathrm{Pd}_{1} \mathrm{Ir}_{1} @ \mathrm{Pt} / \mathrm{C}$ ? Since the lower Pt loading of $\mathrm{Pd}_{1} \mathrm{Ir}_{1} \mathrm{Ni}_{2} @ \mathrm{Pt} / \mathrm{C}$ indicates that $\mathrm{Ni}$ was not replaced with $\mathrm{Pt}$, we suggest that the porous structure created by the dissolution of $\mathrm{Ni}$ may be the reason for the enhanced mass activity of $\mathrm{Pd}_{1} \mathrm{Ir}_{1} \mathrm{Ni}_{2} @ \mathrm{Pt} / \mathrm{C}$.

Figure 6 shows the ORR polarization curves of the catalysts containing various amounts of $\mathrm{Ni}$ and of $20 \% \mathrm{JM}$ $\mathrm{Pt} / \mathrm{C}$ at $1600 \mathrm{rpm}$ in oxygen-saturated $0.1 \mathrm{M} \mathrm{HClO}_{4}$. These results confirm that $\mathrm{Pd}_{1} \mathrm{Ir}_{1} \mathrm{Ni}_{2} @ \mathrm{Pt} / \mathrm{C}$ exhibited the best ORR performance, implying that higher or lower $\mathrm{Ni}$ content may not be beneficial.

Figure 7(a) shows the rotating disk electrode (RDE) measurements for the ORR on $\mathrm{Pd}_{1} \mathrm{Ir}_{1} \mathrm{Ni}_{2} @ \mathrm{Pt} / \mathrm{C}$ in 
$\mathrm{Pd}_{1} \mathrm{Ir}_{1} \mathrm{Ni}_{2} / \mathrm{C}$

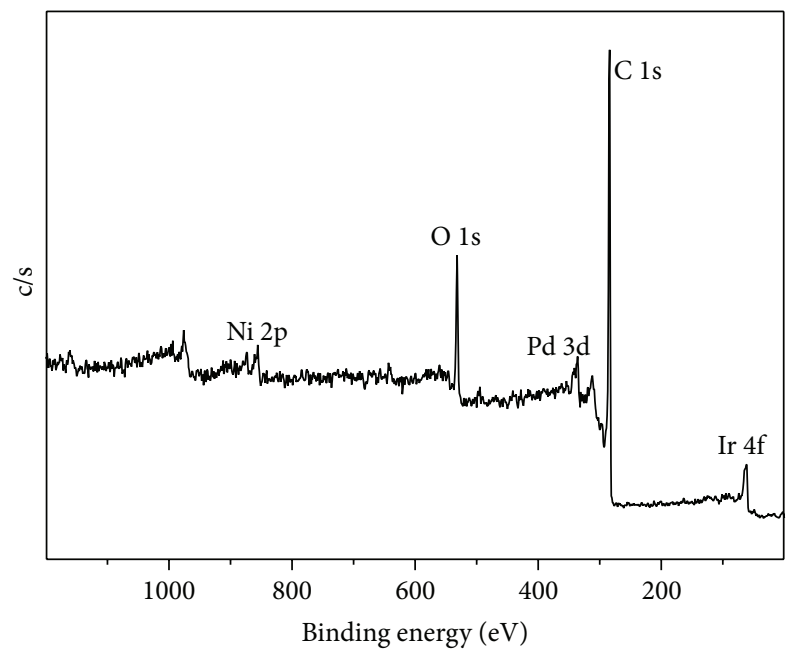

(a)

$\mathrm{Pd}_{1} \mathrm{Ir}_{1} \mathrm{Ni}_{2} / \mathrm{C}$

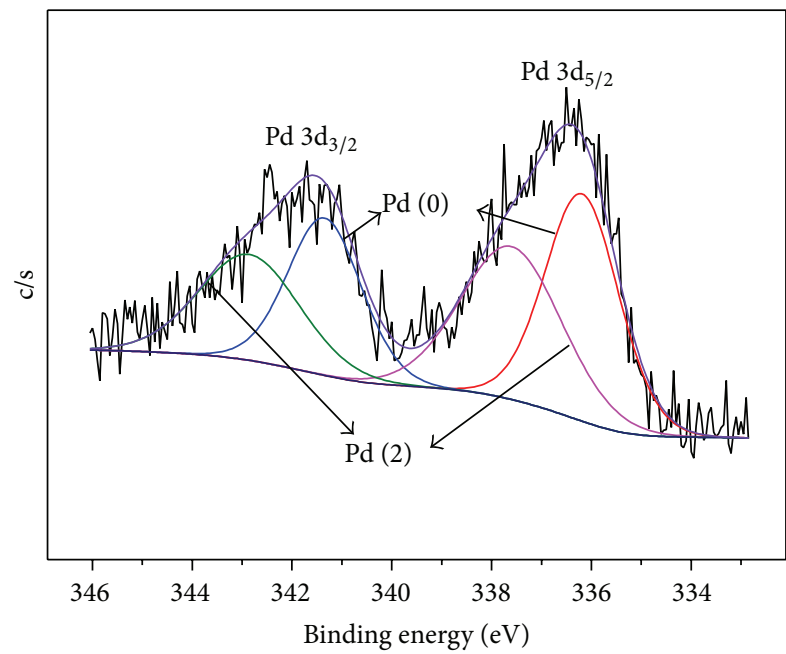

(c)

$\mathrm{Pd}_{1} \mathrm{Ir}_{1} \mathrm{Ni}_{2} / \mathrm{C}$

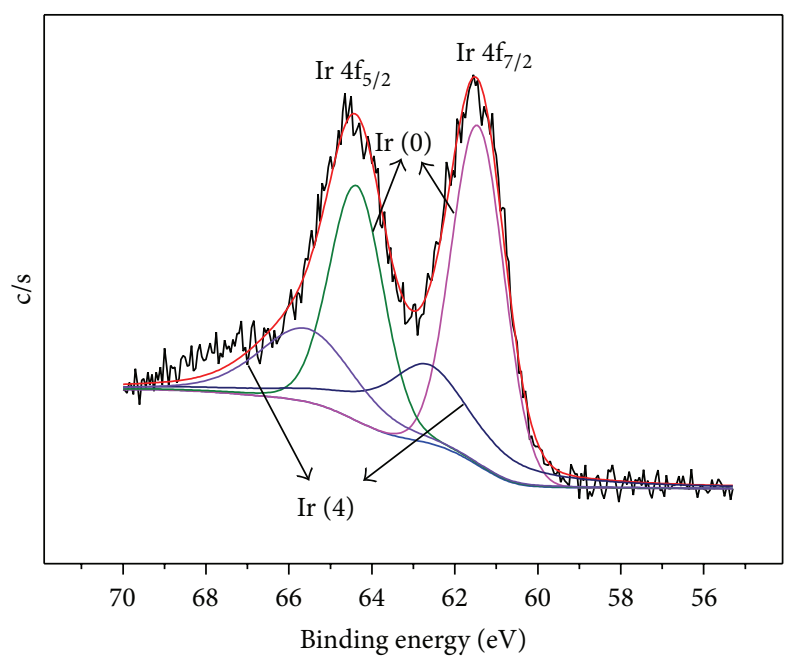

(e)
$\mathrm{Pd}_{1} \mathrm{Ir}_{1} \mathrm{Ni}_{2} @ \mathrm{Pt} / \mathrm{C}$

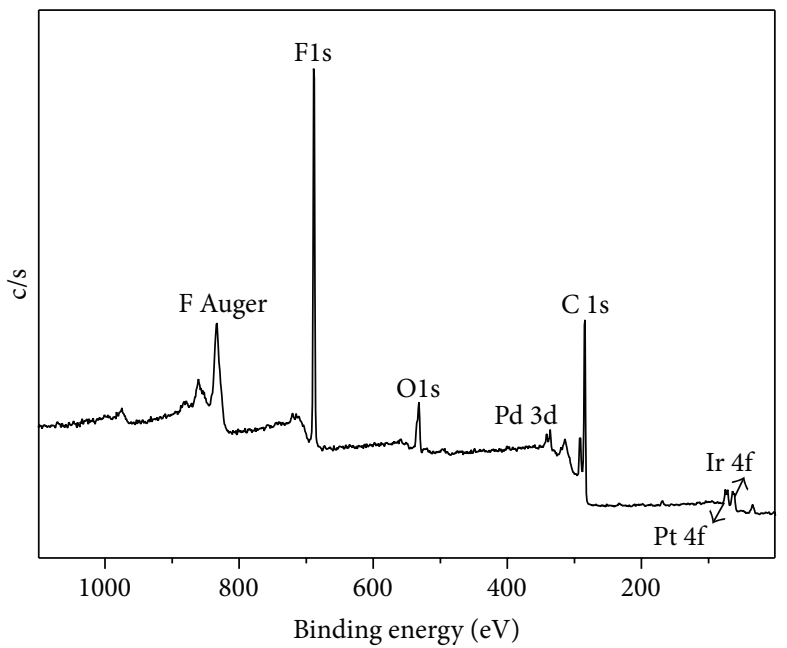

(b)

$\mathrm{Pd}_{1} \mathrm{Ir}_{1} \mathrm{Ni}_{2} @ \mathrm{Pt} / \mathrm{C}$

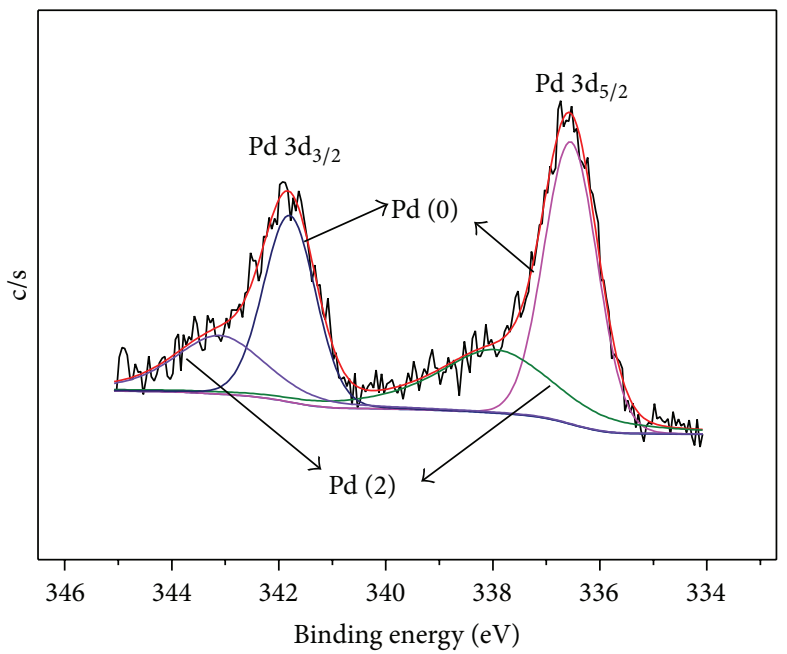

(d)

$\mathrm{Pd}_{1} \mathrm{Ir}_{1} \mathrm{Ni}_{2} @ \mathrm{Pt} / \mathrm{C}$

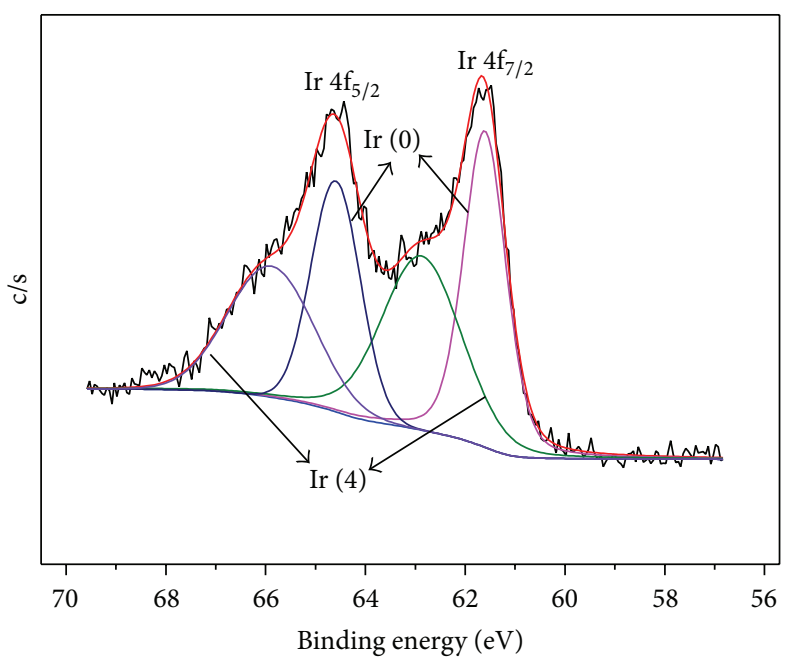

(f)

Figure 3: Continued. 


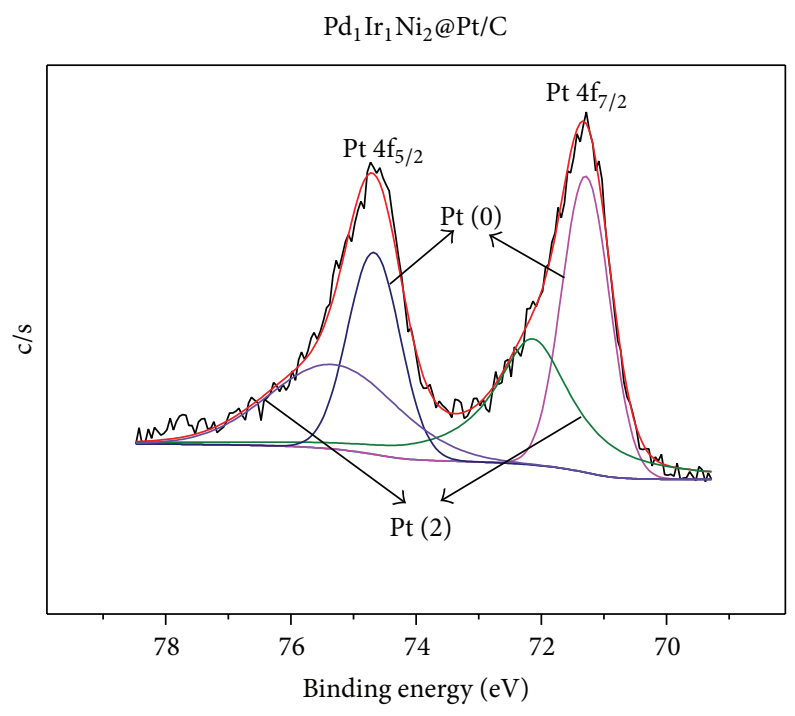

(g)

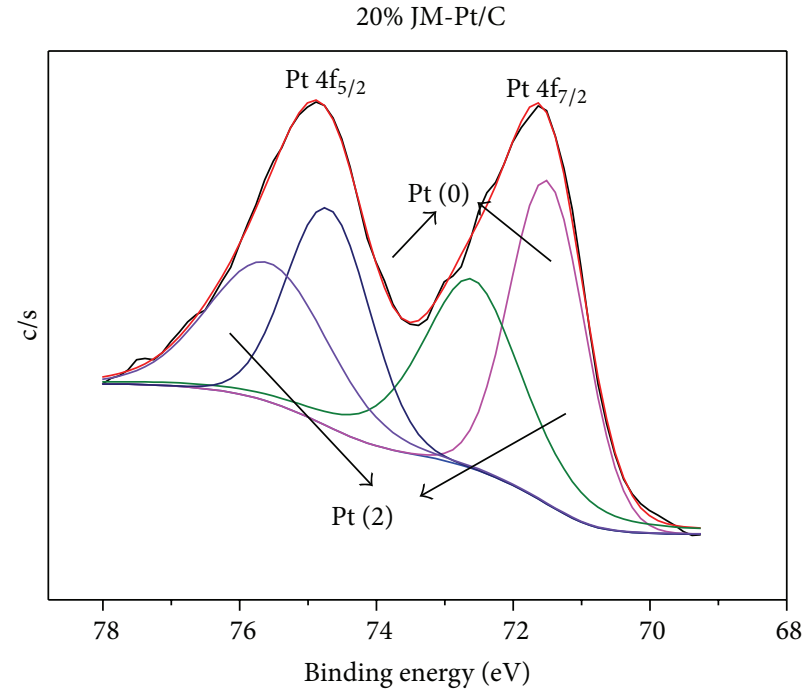

(h)

FIGURE 3: (a) XPS survey spectrum and corresponding high-resolution spectrum of (c) $\mathrm{Pd} 3 \mathrm{~d}$ and (e) $\operatorname{Ir} 4 \mathrm{f}$ for $\mathrm{Pd}_{1} \mathrm{Ir}_{1} \mathrm{Ni}_{2} / \mathrm{C}$; (b) survey spectrum and corresponding high-resolution spectrum of (d) Pd 3d, (f) Ir 4f, and (g) Pt 4f for $\mathrm{Pd}_{1} \mathrm{Ir}_{1} \mathrm{Ni}_{2} @ \mathrm{Pt} / \mathrm{C}$; (h) Pt 4f in 20\% JM-Pt/C.

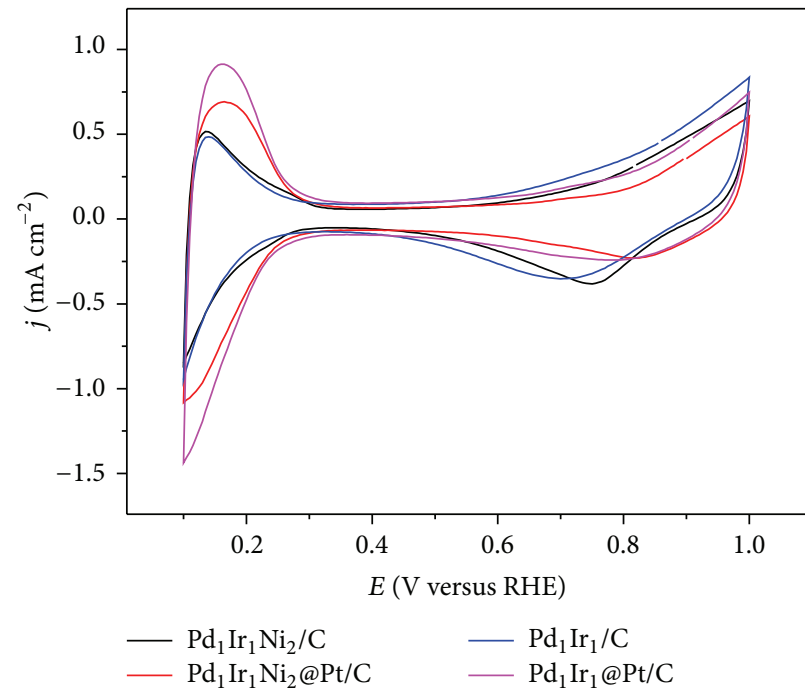

(a)

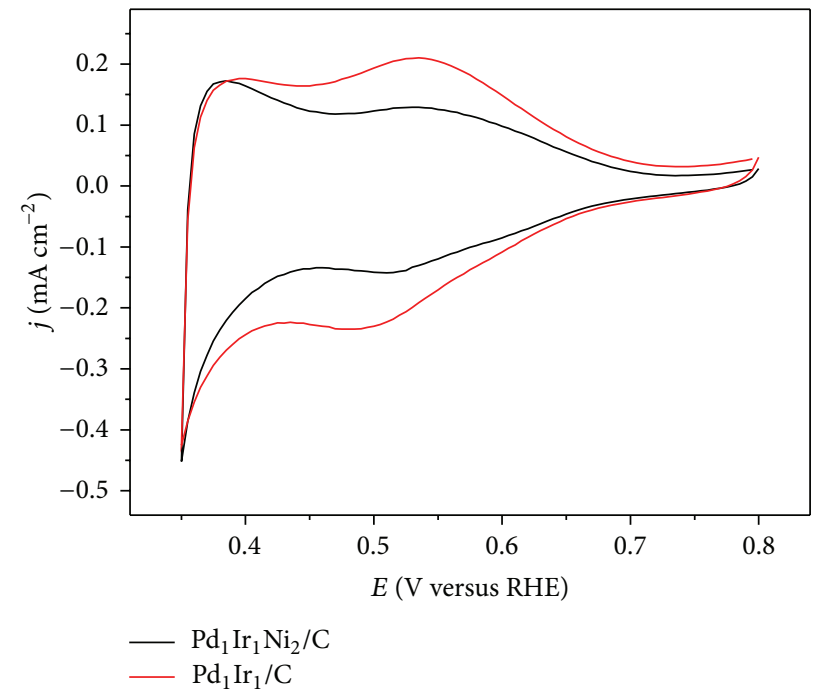

(b)

Figure 4: (a) The cyclic voltammetry curves for $\mathrm{Pd}_{1} \mathrm{Ir}_{1} / \mathrm{C}, \mathrm{Pd}_{1} \mathrm{Ir}_{1} @ \mathrm{Pt} / \mathrm{C}, \mathrm{Pd}_{1} \mathrm{Ir}_{1} \mathrm{Ni}_{2} / \mathrm{C}$, and $\mathrm{Pd}_{1} \mathrm{Ir}_{1} \mathrm{Ni}_{2} @ \mathrm{Pt} / \mathrm{C}$, recorded in deaerated $0.05 \mathrm{M}$ $\mathrm{H}_{2} \mathrm{SO}_{4}$ at a scan rate of $50 \mathrm{mV} \mathrm{s}^{-1}$. (b) CV curves from $\mathrm{Pd}_{1} \mathrm{Ir}_{1} / \mathrm{C}$ and $\mathrm{Pd}_{1} \mathrm{Ir}_{1} \mathrm{Ni}_{2} / \mathrm{C}$ in deaerated $0.05 \mathrm{M} \mathrm{H}_{2} \mathrm{SO}_{4}+0.05 \mathrm{M} \mathrm{CuSO}_{4}$ solution with a scan rate of $10 \mathrm{mV} \mathrm{s}^{-1}$.

TABLE 2: Pt and Ni content determined by ICP-AES.

\begin{tabular}{lccc}
\hline Sample & Actual Ni content (wt\%) & Theoretical Pt content (wt\%) & Actual Pt content (wt\%) \\
\hline $\mathrm{Pd}_{1} \mathrm{Ir}_{1} \mathrm{Ni}_{2} / \mathrm{C}$ & 5.06 & - & - \\
$\mathrm{Pd}_{1} \mathrm{Ir}_{1} \mathrm{Ni}_{2} / \mathrm{C}$ after 20 cycles & 0.05 & - & - \\
$\mathrm{Pd}_{1} \mathrm{Ir}_{1} \mathrm{Ni}_{2} @ \mathrm{Pt} / \mathrm{C}$ & 0.05 & 4.16 & 4.02 \\
$\mathrm{Pd}_{2} \mathrm{Ir}_{2} \mathrm{Ni}_{1} / \mathrm{C}$ & 1.52 & - & - \\
$\mathrm{Pd}_{2} \mathrm{Ir}_{2} \mathrm{Ni}_{1} / \mathrm{C}$ after 20 cycles & 0.33 & - & - \\
$\mathrm{Pd}_{2} \mathrm{Ir}_{2} \mathrm{Ni}_{1} @ \mathrm{Pt} / \mathrm{C}$ & 0.31 & 5.98 & 4.57 \\
$\mathrm{Pd}_{1} \mathrm{Ir}_{1} @ \mathrm{Pt} / \mathrm{C}$ & - & 4.72 & 5.47 \\
\hline
\end{tabular}




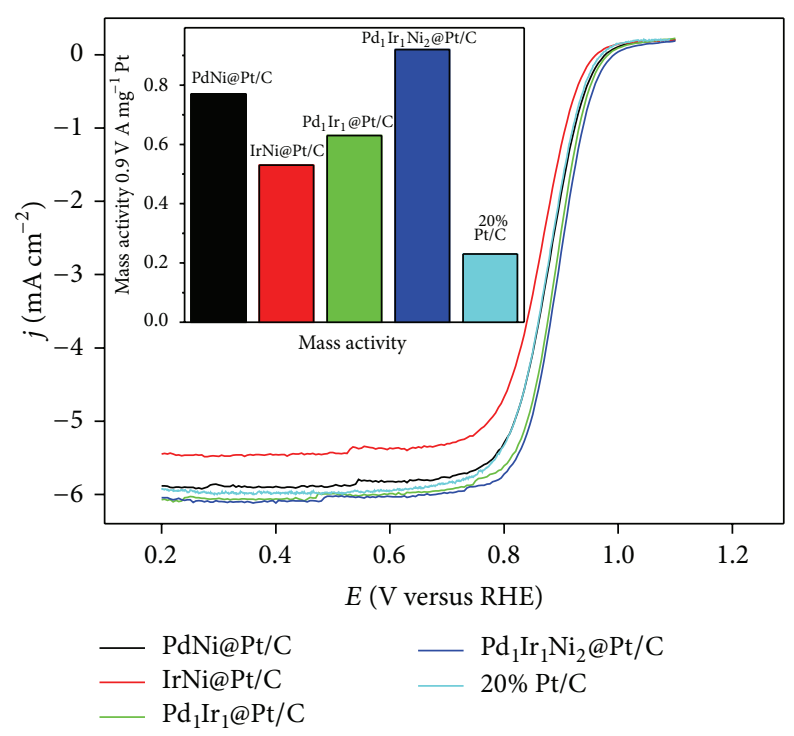

Figure 5: ORR polarization curves of PdNi@Pt/C, IrNi@Pt/C, $\mathrm{Pd}_{1} \mathrm{Ir}_{1} @ \mathrm{Pt} / \mathrm{C}, \mathrm{Pd}_{1} \mathrm{Ir}_{1} \mathrm{Ni}_{2} @ \mathrm{Pt} / \mathrm{C}$, and 20\% JM-Pt/C, each in 0.1 M HClO .

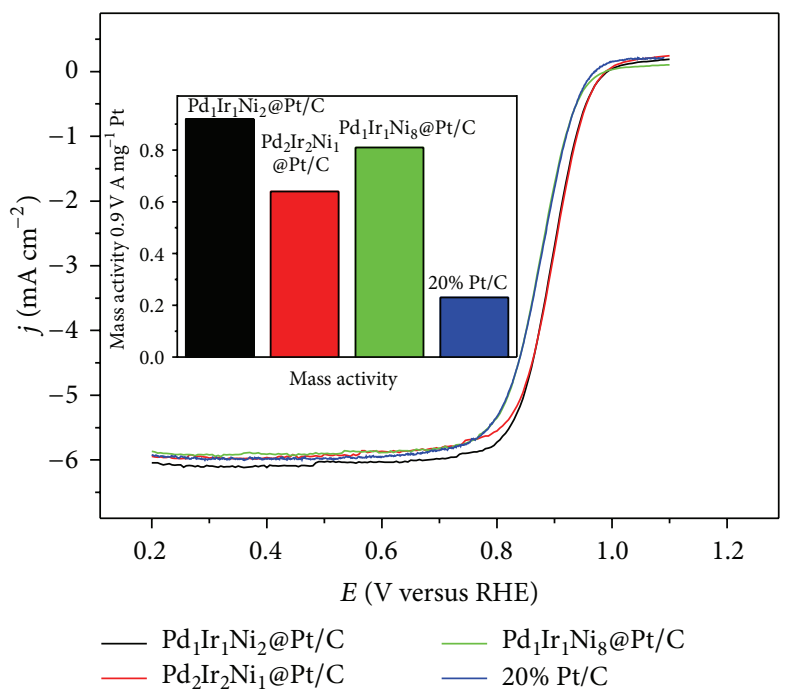

FIGURE 6: ORR polarization curves of the core-shell catalysts with various amounts of $\mathrm{Ni}$ added to the core and of $20 \% \mathrm{Pt} / \mathrm{C}$, in $0.1 \mathrm{M} \mathrm{HClO}_{4}$ solution.

oxygen-saturated $0.1 \mathrm{M} \mathrm{HClO}_{4}$ at different rotation speeds (400-2500 rpm). The Koutecky-Levich plots obtained from Figure 7 (a) with the inverse current density $(1 / j)$ as a function of the inverse of the square root of the rotation rate $\left(\omega^{1 / 2}\right)$ are presented in Figure $7(\mathrm{~b})$. Using the average slopes of the Koutecky-Levich plots and the equation $B=0.62 n F A D_{\mathrm{O}_{2}}^{2 / 3} v^{-1 / 6} C_{\mathrm{O}_{2}}\left(D_{\mathrm{O}_{2}}=1.93 \times 10^{-5} \mathrm{~cm}^{2} \mathrm{~s}^{-1}\right.$, $v=1.009 \times 10^{-2} \mathrm{~cm}^{2} \mathrm{~s}^{-1}, C_{\mathrm{O}_{2}}=1.26 \times 10^{-3} \mathrm{~mol} \mathrm{~L}^{-1}$, $F$ is the Faraday constant, and $A$ is the geometric area of the electrode) [30], we calculated that the electron transfer number, $n$, was 4.12 , indicating that the ORR on $\mathrm{Pd}_{1} \mathrm{Ir}_{1} \mathrm{Ni}_{2} @ \mathrm{Pt} / \mathrm{C}$ predominantly followed the four-electron exchange pathway. Moreover, the linearity and parallelism of the plots shown in Figure 7(b) are signs of first-order kinetics with respect to molecular oxygen [31]. The Tafel plot obtained from the kinetic current, $j_{k}$, is shown in the inset of
Figure $7(\mathrm{~b})$. The plot is linear, with a slope of $\sim-68 \mathrm{mV} \mathrm{dec}{ }^{-1}$ above $0.80 \mathrm{~V}$.

Figures $7(\mathrm{c})$ and $7(\mathrm{~d})$ show the ORR curves at various rotation speeds on $\mathrm{Ir}_{1} \mathrm{Ni}_{2} @ \mathrm{Pt} / \mathrm{C}$, and the $\mathrm{K}-\mathrm{L}$ plots derived from the curves at various potentials. From the slopes of the $\mathrm{K}-\mathrm{L}$ plots, the calculated electron transfer number is 4.30 , revealing that the ORR on $\mathrm{Ir}_{1} \mathrm{Ni}_{2} @ \mathrm{Pt} / \mathrm{C}$ also followed the four-electron transfer pathway.

The values of the Tafel slopes of $\mathrm{Ir}_{1} \mathrm{Ni}_{2} @ \mathrm{Pt} / \mathrm{C}$ were about -70.2 and $-93.1 \mathrm{mV} \mathrm{dec}^{-1}$, which differ from the slope of $-68 \mathrm{mV} \mathrm{dec}{ }^{-1}$ obtained for $\mathrm{Pd}_{1} \mathrm{Ir}_{1} \mathrm{Ni}_{2} @ \mathrm{Pt} / \mathrm{C}$ [32]. The latter's lower Tafel slope may be attributed to the addition of Pd.

3.3. Stability. The $\mathrm{Pd}_{1} \mathrm{Ir}_{1} \mathrm{Ni}_{2} @ \mathrm{Pt} / \mathrm{C}$ core-shell structured catalyst exhibited excellent stability, as shown in Figure 8(a). After 10,000 CV cycles in nitrogen-saturated $0.05 \mathrm{~mol} \mathrm{~L}^{-1}$ 


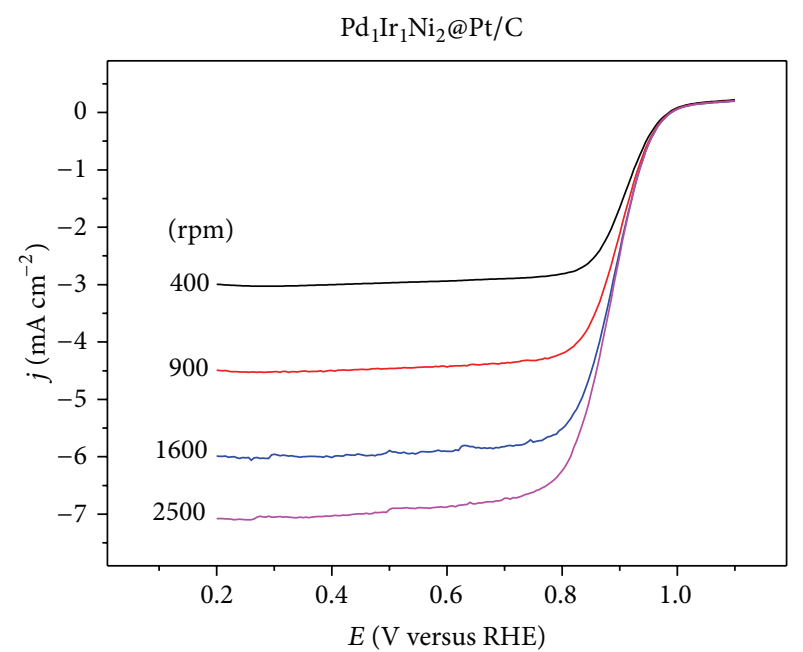

(a)

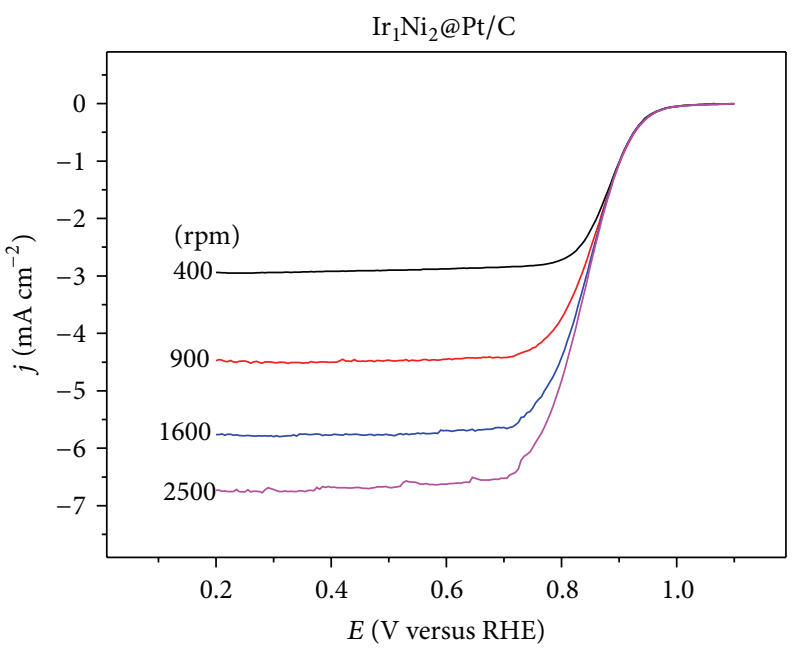

(c)

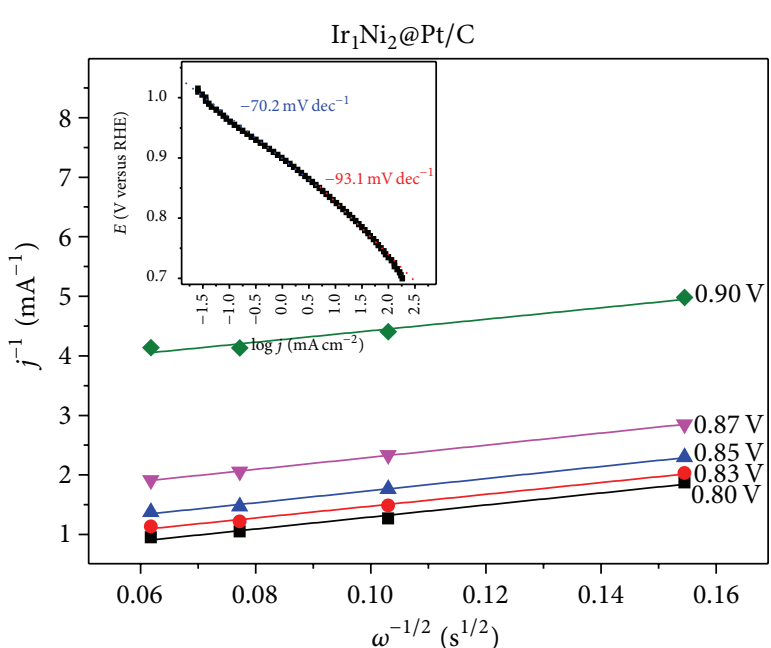

(b)

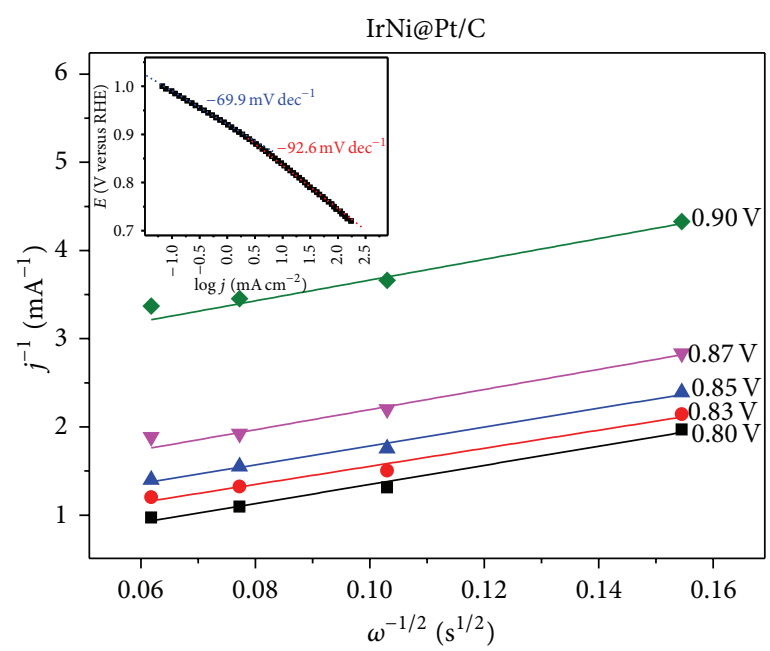

(d)

Figure 7: ((a), (c)) Polarization curves of $\mathrm{Pd}_{1} \mathrm{Ir}_{1} \mathrm{Ni}_{2} @ \mathrm{Pt} / \mathrm{C}$ and $\mathrm{Ir}_{1} \mathrm{Ni}_{2} @ \mathrm{Pt} / \mathrm{C}$, obtained with a rotating disk electrode for the ORR in $0.1 \mathrm{M}$ $\mathrm{HClO}_{4}$ solution. ((b), (d)) Koutecky-Levich plots at different potentials using the data obtained from $\mathrm{Pd}_{1} \mathrm{Ir}_{1} \mathrm{Ni}_{2} @ \mathrm{Pt} / \mathrm{C}$ and $\mathrm{Ir}_{1} \mathrm{Ni}_{2} @ \mathrm{Pt} / \mathrm{C}$ (Figures $7(\mathrm{a})$ and $7(\mathrm{c})$ ).

$\mathrm{H}_{2} \mathrm{SO}_{4}$ solution, the ECSA decay was only $9.4 \%$, compared to 28.1\% for commercial Pt/C. Furthermore, after 10,000 ORR scans, the ORR performance of $\mathrm{Pd}_{1} \mathrm{Ir}_{1} \mathrm{Ni}_{2} @ \mathrm{Pt} / \mathrm{C}$ was almost unchanged, whilst for commercial Pt/C and home-prepared Pd@Pt catalyst the decay was 34.7\% and 39.2\%, respectively, indicating the outstanding stability of our core-shell structured catalyst with a Pt monolayer around a ternary alloy core.

\section{Conclusions}

A high-performance, highly stable core-shell structured catalyst with a Pt monolayer shell and a ternary alloy nanoparticle core has been successfully prepared via a UPD method, and the catalyst has been characterized using XRD, TEM, and XPS. The catalyst exhibited very high ORR activity and excellent stability. We found that the Ni added to the alloy played an important role in significantly enhancing the
ORR performance, and we suggest that the formation of a porous structure-caused by the dissolution of $\mathrm{Ni}$ in the alloy nanoparticles, which left only residual $\mathrm{Ni}$ nanoparticlesmay be the main reason for the catalyst's enhanced performance. After 10,000 ORR scans, the half-wave potential was almost unchanged, indicating this catalyst's outstanding stability.

\section{Conflict of Interests}

The authors declare that there is no conflict of interests regarding the publication of this paper.

\section{Acknowledgments}

This work was supported by the National Science Foundation of China (NSFC Project nos. 21276098, 21476088, 


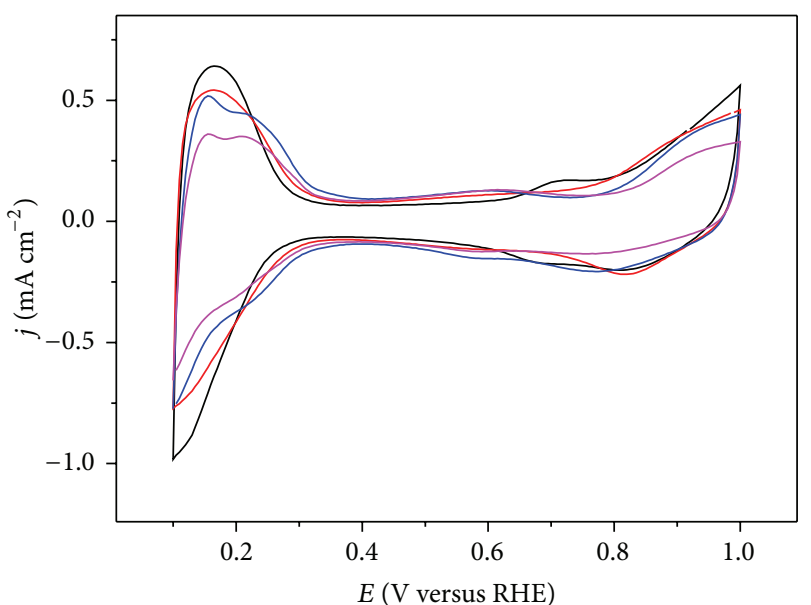

$\begin{array}{ll}-\mathrm{Pd}_{1} \mathrm{Ir}_{1} \mathrm{Ni}_{2} @ \mathrm{Pt} / \mathrm{C} & -20 \% \mathrm{Pt} / \mathrm{C} \\ -\mathrm{Pd}_{1} \mathrm{Ir}_{1} \mathrm{Ni}_{2} @ \mathrm{Pt} / \mathrm{C}-10000 \mathrm{cls}-20 \% \mathrm{Pt} / \mathrm{C}-10000 \mathrm{cls}\end{array}$

(a)

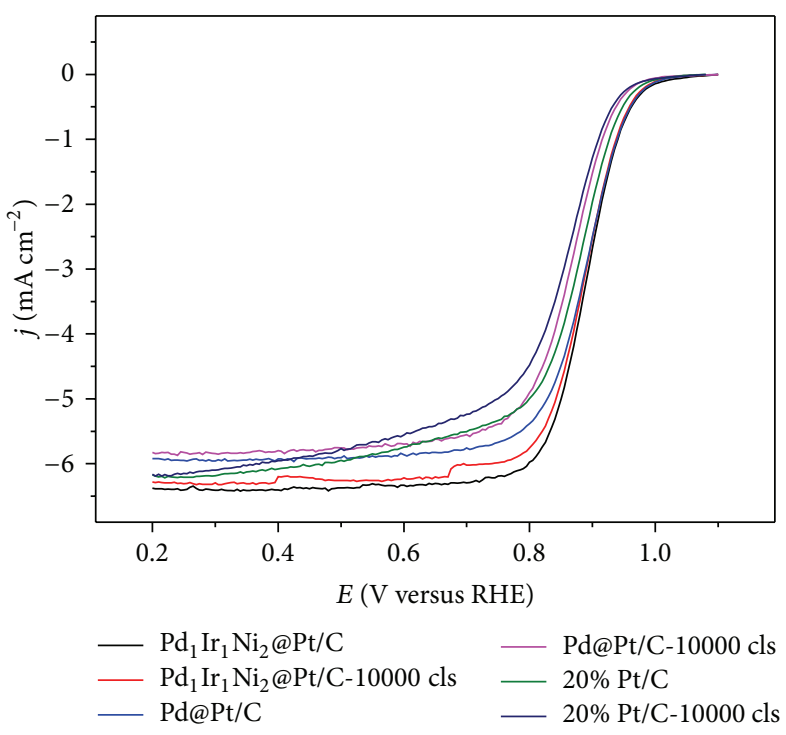

(b)

Figure 8: (a) CV curves of $\mathrm{Pd}_{1} \mathrm{Ir}_{1} \mathrm{Ni}_{2} @ \mathrm{Pt} / \mathrm{C}$ and 20\% JM-Pt/C at initial scanning and after 10,000 scans in deaerated $0.05 \mathrm{M} \mathrm{H}_{2} \mathrm{SO}_{4}$ at a scan rate of $50 \mathrm{mV} \mathrm{s}^{-1}$. (b) ORR curves of $\mathrm{Pd}_{1} \mathrm{Ir}_{1} \mathrm{Ni}_{2} @ \mathrm{Pt} / \mathrm{C}, \mathrm{Pd} @ \mathrm{Pt} / \mathrm{C}$, and 20\% JM-Pt/C at initial scanning and after 10,000 scans.

51302091, and U1301245), Ministry of Science and Technology of China (Project no. 2012AA053402), Guangdong Natural Science Foundation (Project no. S2012020011061), and Department of Education of Guangdong Province (Project no. 2013CXZDA003).

\section{References}

[1] G. Wu, K. L. More, C. M. Johnston, and P. Zelenay, "Highperformance electrocatalysts for oxygen reduction derived from polyaniline, iron, and cobalt," Science, vol. 332, no. 6028, pp. 443-447, 2011.

[2] L. M. Vracar, D. B. Sepa, and A. Damjanovic, "Palladium electrode in oxygen-saturated aqueous solutions: reduction of oxygen in the activation-controlled region," Journal of the Electrochemical Society, vol. 133, no. 9, pp. 1835-1839, 1986.

[3] E. Antolini, "Iridium application in low-temperature acidic fuel cells: Pt-free Ir-based catalysts or second/third promoting metal in Pt-based catalysts?" ChemElectroChem, vol. 1, no. 2, pp. 318328, 2014.

[4] J. Guo, A. Hsu, D. Chu, and R. Chen, "Improving oxygen reduction reaction activities on carbon-supported Ag nanoparticles in alkaline solutions," Journal of Physical Chemistry C, vol. 114, no. 10, pp. 4324-4330, 2010.

[5] J. Zhang, K. Sasaki, E. Sutter, and R. R. Adzic, "Stabilization of platinum oxygen-reduction electrocatalysts using gold clusters," Science, vol. 315, no. 5809, pp. 220-222, 2007.

[6] H. Peng, Z. Mo, S. Liao et al., "High performance Fe- and $\mathrm{N}$-doped carbon catalyst with graphene structure for oxygen reduction," Scientific Reports, vol. 3, article 1765, 2013.

[7] W. Yang, X. Liu, X. Yue, J. Jia, and S. Guo, "Bamboo-like carbon nanotube $/ \mathrm{Fe}_{3} \mathrm{C}$ nanoparticle hybrids and their highly efficient catalysis for oxygen reduction," Journal of the American Chemical Society, vol. 137, no. 4, pp. 1436-1439, 2015.

[8] D. Wang, H. L. Xin, R. Hovden et al., "Structurally ordered intermetallic platinum-cobalt core-shell nanoparticles with enhanced activity and stability as oxygen reduction electrocatalysts," Nature Materials, vol. 12, no. 1, pp. 81-87, 2013.

[9] K. A. Kuttiyiel, K. Sasaki, Y. Choi, D. Su, P. Liu, and R. R. Adzic, "Nitride stabilized PtNi core-shell nanocatalyst for high oxygen reduction activity," Nano Letters, vol. 12, no. 12, pp. 6266-6271, 2012.

[10] T.-Y. Jeon, N. Pinna, S. J. Yoo et al., "Selective deposition of Pt onto supported metal clusters for fuel cell electrocatalysts," Nanoscale, vol. 4, no. 20, pp. 6461-6469, 2012.

[11] D. Chen, R. Chen, D. Dang, T. Shu, H. Peng, and S. Liao, "High performance of core-shell structured Ir@Pt/C catalyst prepared by a facile pulse electrochemical deposition," Electrochemistry Communications, vol. 46, pp. 115-119, 2014.

[12] X. Lu, F. Luo, H. Song, S. Liao, and H. Li, "Pulse electrodeposition to prepare core-shell structured AuPt@Pd/C catalyst for formic acid fuel cell application," Journal of Power Sources, vol. 246, pp. 659-666, 2014.

[13] S. R. Branković, J. X. Wang, and R. R. Adžić, "New methods of controlled monolayer-to-multilayer deposition of $\mathrm{Pt}$ for designing electrocatalysts at an atomic level," Journal of the Serbian Chemical Society, vol. 66, no. 11-12, pp. 887-898, 2001.

[14] K. Sasaki, Y. Mo, J. X. Wang et al., "Pt submonolayers on metal nanoparticles-novel electrocatalysts for $\mathrm{H}_{2}$ oxidation and $\mathrm{O}_{2}$ reduction," Electrochimica Acta, vol. 48, no. 25-26, pp. 38413849, 2003.

[15] J. Zhang, F. H. B. Lima, M. H. Shao et al., "Platinum monolayer on nonnoble metal-noble metal core-shell nanoparticle electrocatalysts for $\mathrm{O}_{2}$ reduction," The Journal of Physical Chemistry B, vol. 109, no. 48, pp. 22701-22704, 2005.

[16] K. Sasaki, H. Naohara, Y. Cai et al., "Core-protected platinum monolayer shell high-stability electrocatalysts for fuel-cell cathodes," Angewandte Chemie-International Edition, vol. 49, no. 46, pp. 8602-8607, 2010.

[17] T. Ghosh, M. B. Vukmirovic, F. J. DiSalvo, and R. R. Adzic, "Intermetallics as novel supports for $\mathrm{Pt}$ monolayer $\mathrm{O}_{2}$ reduction 
electrocatalysts: potential for significantly improving properties," Journal of the American Chemical Society, vol. 132, no. 3, pp. 906-907, 2010.

[18] K. Gong, J. Park, D. Su, and R. R. Adzic, "Metalizing carbon nanotubes with $\mathrm{Pd}-\mathrm{Pt}$ core-shell nanowires enhances electrocatalytic activity and stability in the oxygen reduction reaction," Journal of Solid State Electrochemistry, vol. 18, no. 5, pp. 11711179, 2014.

[19] M. Shao, K. Shoemaker, A. Peles, K. Kaneko, and L. Protsailo, "Pt monolayer on porous $\mathrm{Pd}-\mathrm{Cu}$ alloys as oxygen reduction electrocatalysts," Journal of the American Chemical Society, vol. 132, no. 27, pp. 9253-9255, 2010.

[20] H. I. Karan, K. Sasaki, K. Kuttiyiel, C. A. Farberow, M. Mavrikakis, and R. R. Adzic, "Catalytic activity of platinum monolayer on iridium and rhenium alloy nanoparticles for the oxygen reduction reaction," ACS Catalysis, vol. 2, no. 5, pp. 817$824,2012$.

[21] S. R. Brankovic, J. X. Wang, and R. R. Adžić, "Metal monolayer deposition by replacement of metal adlayers on electrode surfaces," Surface Science, vol. 474, no. 1-3, pp. L173-L179, 2001.

[22] S. T. Bliznakov, M. B. Vukmirovic, L. Yang, E. A. Sutter, and R. R. Adzic, "Pt monolayer on electrodeposited Pd nanostructures: advanced cathode catalysts for PEM fuel cells," Journal of the Electrochemical Society, vol. 159, no. 9, pp. F501-F506, 2012.

[23] W.-P. Zhou, X. Yang, M. B. Vukmirovic et al., "Improving electrocatalysts for $\mathrm{O}_{2}$ reduction by fine-tuning the Pt-support interaction: Pt monolayer on the surfaces of a $\mathrm{Pd}_{3} \mathrm{Fe}(111)$ singlecrystal alloy," Journal of the American Chemical Society, vol. 131, no. 35, pp. 12755-12762, 2009.

[24] M. Shao, K. Sasaki, N. S. Marinkovic, L. Zhang, and R. R. Adzic, "Synthesis and characterization of platinum monolayer oxygenreduction electrocatalysts with Co-Pd core-shell nanoparticle supports," Electrochemistry Communications, vol. 9, no. 12, pp. 2848-2853, 2007.

[25] K. A. Kuttiyiel, K. Sasaki, D. Su, M. B. Vukmirovic, N. S. Marinkovic, and R. R. Adzic, "Pt monolayer on Au-stabilized PdNi core-shell nanoparticles for oxygen reduction reaction," Electrochimica Acta, vol. 110, pp. 267-272, 2013.

[26] S. L. Knupp, M. B. Vukmirovic, P. Haldar, J. A. Herron, M. Mavrikakis, and R. R. Adzic, "Platinum monolayer electrocatalysts for $\mathrm{O}_{2}$ reduction: Pt monolayer on carbon-supported PdIr nanoparticles," Electrocatalysis, vol. 1, no. 4, pp. 213-223, 2010.

[27] J. Qiao, B. Li, and J. Ma, "Carbon-supported IrM ( $\mathrm{M}=\mathrm{V}, \mathrm{Mn}$, $\mathrm{Fe}, \mathrm{Co}$, and $\mathrm{Ni}$ ) binary alloys as anode catalysts for polymer electrolyte fuel cells," Journal of the Electrochemical Society, vol. 156, no. 4, pp. B436-B440, 2009.

[28] G. Wang, B. Huang, L. Xiao et al., "Pt skin on AuCu intermetallic substrate: a strategy to maximize Pt utilization for fuel cells," Journal of the American Chemical Society, vol. 136, no. 27, pp. 9643-9649, 2014.

[29] Y. Zhang, C. Ma, Y. Zhu et al., "Hollow core supported Pt monolayer catalysts for oxygen reduction," Catalysis Today, vol. 202, no. 1, pp. 50-54, 2013.

[30] K. Sasaki, L. Zhang, and R. R. Adzic, "Niobium oxide-supported platinum ultra-low amount electrocatalysts for oxygen reduction," Physical Chemistry Chemical Physics, vol.10, no. 1, pp. 159167, 2008.

[31] N. A. Anastasijević, V. Vesović, and R. R. Adžić, "Determination of the kinetic parameters of the oxygen reduction reaction using the rotating ring-disk electrode. Part I. Theory," Journal of Electroanalytical Chemistry and Interfacial Electrochemistry, vol. 229, no. 1-2, pp. 305-316, 1987.
[32] J. Zhang, Y. Mo, M. B. Vukmirovic, R. Klie, K. Sasaki, and R. R. Adzic, "Platinum monolayer electrocatalysts for $\mathrm{O}_{2}$ reduction: Pt monolayer on $\mathrm{Pd}(111)$ and on carbon-supported Pd nanoparticles," The Journal of Physical Chemistry B, vol. 108, no. 30, pp. 10955-10964, 2004. 

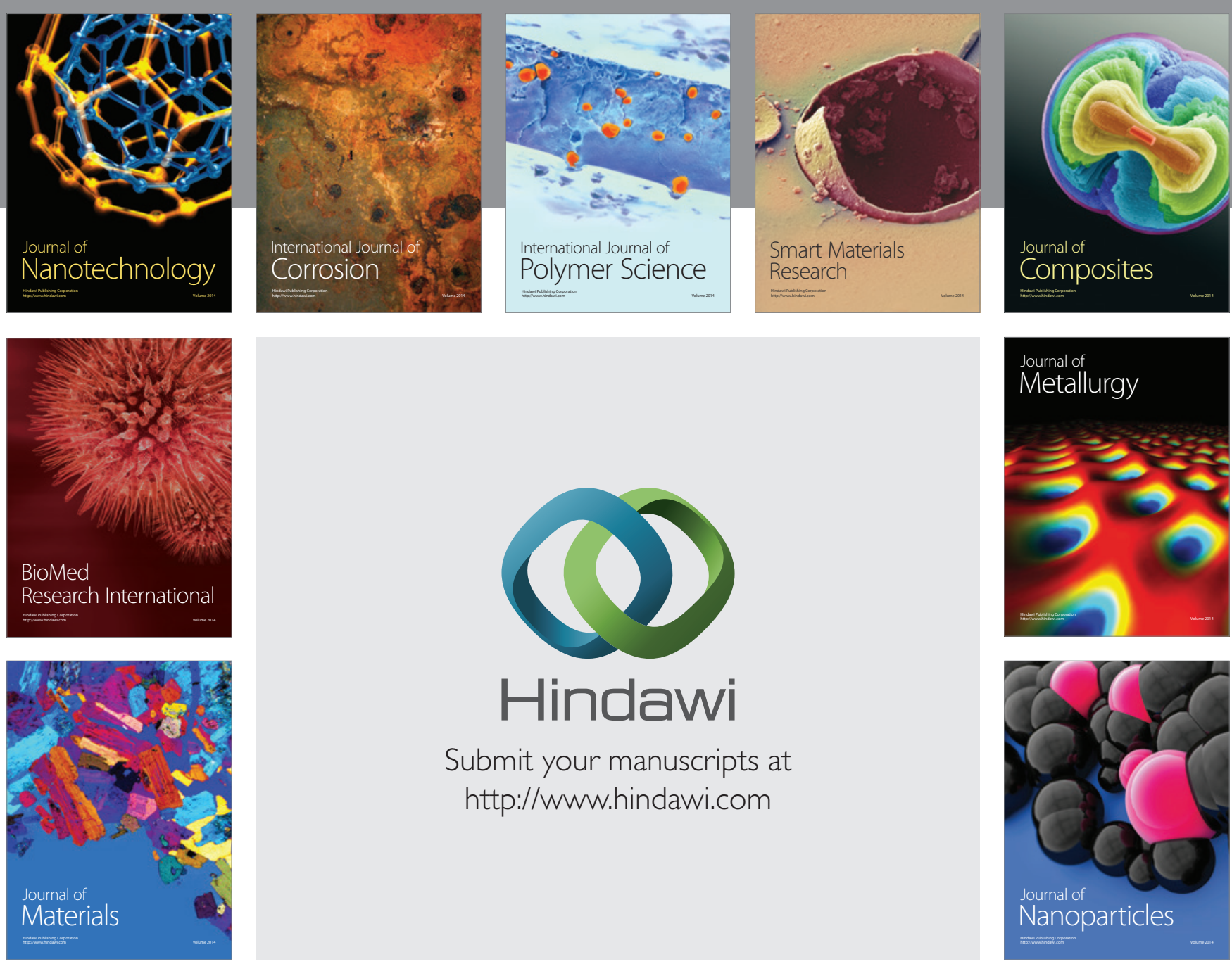

Submit your manuscripts at http://www.hindawi.com
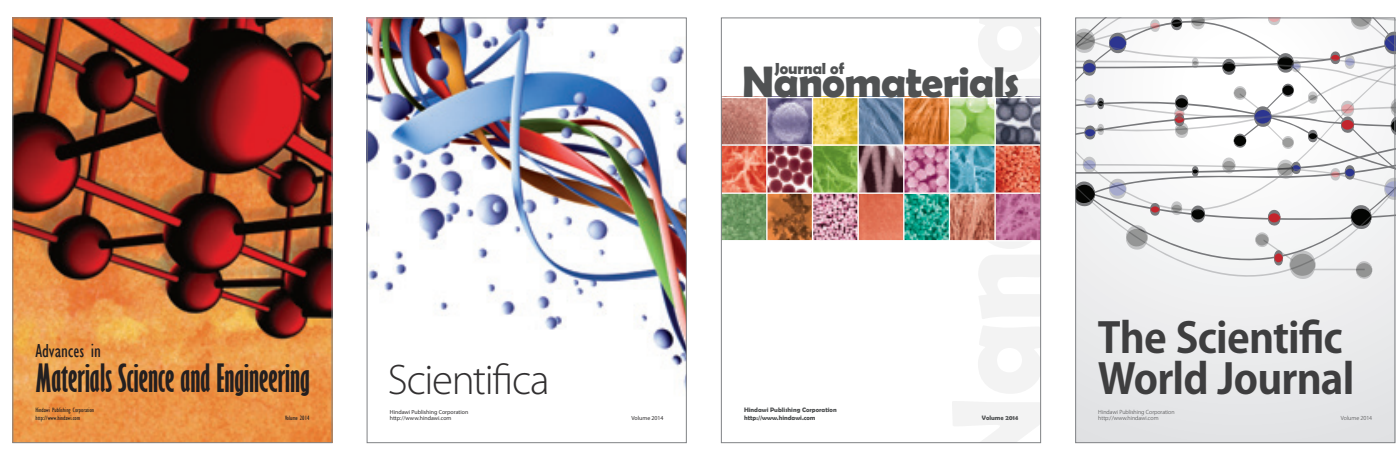

\section{The Scientific World Journal}
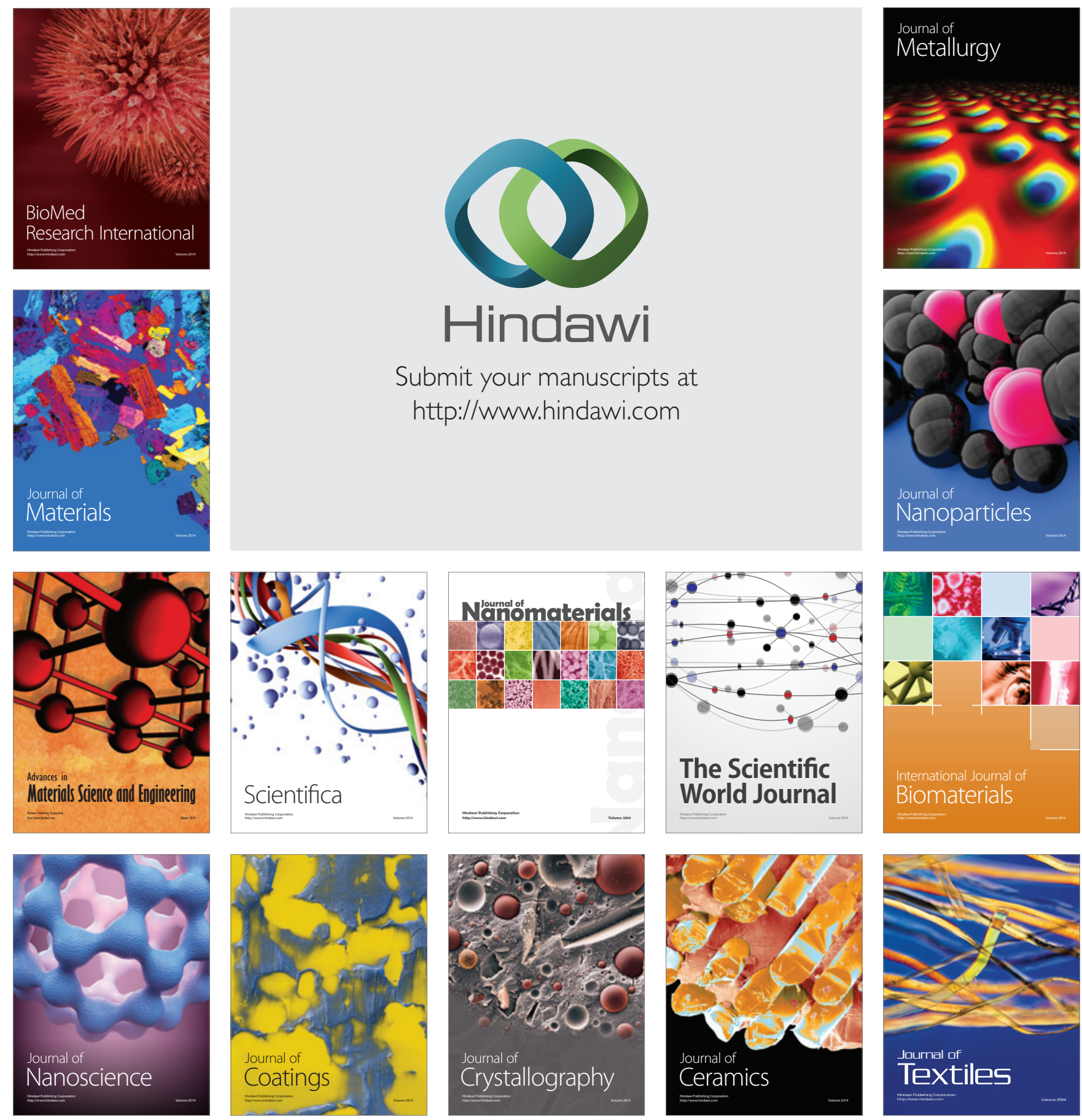